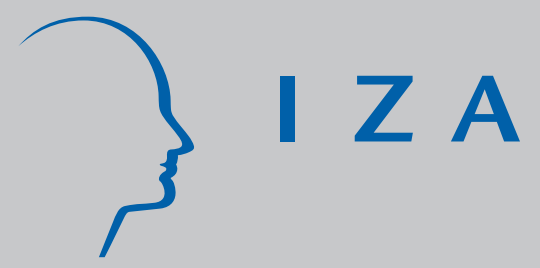

IZA DP No. 368

How Do Sex Ratios Affect Marriage and Labor Markets?

Evidence from America's Second Generation

J oshua Angrist

September 2001 


\title{
How Do Sex Ratios Affect Marriage and Labor Markets? \\ Evidence from America's Second Generation
}

\author{
Joshua Angrist \\ Department of Economics, MIT and IZA, Bonn
}

Discussion Paper No. 368
September 2001

IZA

P.O. Box 7240

D-53072 Bonn

Germany

Tel.: +49-228-3894-0

Fax: +49-228-3894-210

Email: iza@iza.org

This Discussion Paper is issued within the framework of IZA's research area The Future of Work. Any opinions expressed here are those of the author(s) and not those of the institute. Research disseminated by IZA may include views on policy, but the institute itself takes no institutional policy positions.

The Institute for the Study of Labor (IZA) in Bonn is a local and virtual international research center and a place of communication between science, politics and business. IZA is an independent, nonprofit limited liability company (Gesellschaft mit beschränkter Haftung) supported by the Deutsche Post AG. The center is associated with the University of Bonn and offers a stimulating research environment through its research networks, research support, and visitors and doctoral programs. IZA engages in (i) original and internationally competitive research in all fields of labor economics, (ii) development of policy concepts, and (iii) dissemination of research results and concepts to the interested public. The current research program deals with (1) mobility and flexibility of labor markets, (2) internationalization of labor markets and European integration, (3) the welfare state and labor markets, (4) labor markets in transition, (5) the future of work, (6) project evaluation and (7) general labor economics.

IZA Discussion Papers often represent preliminary work and are circulated to encourage discussion. Citation of such a paper should account for its provisional character. 


\title{
ABSTRACT \\ How Do Sex Ratios Affect Marriage and Labor Markets? Evidence from America's Second Generation*
}

\begin{abstract}
Sex ratios, i.e., relative numbers of men and women, can affect marriage prospects, labor force participation, and other social and economic variables. But the observed association between sex ratios and social and economic conditions may be confounded by omitted variables and reverse causality. This paper uses variation in immigrant flows as a natural experiment to study the effect of sex ratios on the children and grandchildren of immigrants. The flow of immigrants affected the second generation marriage market because second generation marriages were mostly endogamous, i.e., to members of the same ethnic group. The empirical results suggest that high sex ratios had a large positive effect on the likelihood of female marriage, and a large negative effect on female labor force participation. Perhaps surprisingly, the marriage rates of second generation men appear to be a slightly increasing function of immigrant sex ratios. Higher sex ratios also appear to have raised male earnings and the incomes of parents with young children. The empirical results are broadly consistent with theories where higher sex ratios increase female bargaining power in the marriage market.
\end{abstract}

JEL Classification: J12, J13, D13, N32

Keywords: Household and family models, immigration, family structure

Joshua Angrist

Department of Economics

MIT

50 Memorial Drive

Cambridge, MA 021242-1347

USA

Tel.: +16172538909

Fax: +16172531330

Email: angrist@economics.mit.edu

\footnotetext{
* Special thanks go to Helen Lee and especially Patrick Buckley for outstanding research assistance. I also thank Alberto Abadie, Daron Acemoglu, David Autor, Dora Costa, Peter Diamond, Larry Katz, Kevin Lang, and seminar participants at the National Bureau of Economic Research Fall Labor Studies meeting, the Massachusetts Institute of Technology, the University of Houston, Rice, Texas A\&M, and the European University Institute for helpful discussions and comments. This is a revised version of National Bureau of Economic Research Working Paper No. 8042.
} 
"There's a shortage of men, so [the men] think, 'I can have more than one woman. I'm gonna go around to this one or that one, and I'm gonna have two or three of them."

(A single Philadelphia mother describes her local marriage market; quoted in Edin, 2000).

"Every day I meet someone better. I am waiting for the best."

(A female Moroccan immigrant describes her local marriage market; quoted in Rodriguez, 2000).

\section{Introduction}

Changes in sex ratios, conventionally defined as the number of men for each woman in a reference population, may have far-reaching consequences. Most immediately, sex ratios are a powerful force affecting marriage rates. But sex ratios may also have more subtle effects that operate even without changing marital status. An increase in the sex ratio may increase female bargaining power in the marriage market, shifting resources and family structures in a way that favors women. Moreover, because sex ratios affect the likelihood of marriage, they may affect activities that complement or substitute for economic dependence on a spouse. For example, women who expect to marry need to worry less about developing an independent means of support. Similarly, men who face a more competitive marriage market need to be more efficient, i.e., to invest in characteristics attractive to mates.

Empirical studies of the consequences of changing sex ratios must contend with the fact that the human sex ratio at birth is reasonably stable at about 1.04 men per woman, an observation that goes back to Fisher [1930]. Although substantial deviations from this ratio have occasionally been reported, the interpretation of abnormal sex ratios at birth is disputed (see, e.g., Sieff [1990]). On the other hand, the virtual sex ratio -- i.e., the number of men available and likely to marry a given woman -- can be highly imbalanced. For example, women in growing populations experience a "marriage squeeze" since men tend to marry younger women (Shoen 1983).

A more dramatic source of behavioral variation in sex ratios is sex-biased migration. International migrants have traditionally been male, so immigrant communities are often characterized by high sex ratios. These migration-induced changes in sex ratios need not be exogenous to economic and social conditions, however. For example, the 1990 census shows that Washington, DC and New York City had considerably 
more women than men in the 18-25 age group, probably because young women were especially likely to move to these cities to study and work. ${ }^{1}$ And many college campuses today have majority female populations (Koerner, 1999). Declining sex ratios in US cities and colleges partly reflect changing opportunities for women.

In this paper, I use a major migration episode in American history to study the consequences of changing sex ratios. My identification strategy exploits variation in the immigrant flow over time and across ethnic groups to estimate the consequences of changing sex ratios for the children of immigrants in the first half of the $20^{\text {th }}$ century. For example, this strategy links changes in the marriage rates of the children of Italian immigrants between 1910 and 1940 with changes in the sex ratio of recently arrived Italian immigrants in this period. There are a number of reasons why this approach provides a good natural experiment. First, immigrant sex ratios had a large effect on the second generation marriage market because endogamous marriages -- i.e., marriages within ethnicity -- accounted for over half of unions in most groups. Second, I argue below that the resulting variation in sex ratios was driven largely by exogenous changes in US immigration law. ${ }^{2}$ Finally, early $20^{\text {th }}$ Century immigrants are an important group; in 1910, almost 40 percent of Whites were of "foreign stock", i.e. foreign-born (16 percent), or of foreign or mixed parentage (23 percent; US Bureau of the Census, 1975).

The outcomes of interest in this study are variables related to marital status and family structure, and economic outcomes like labor force participation, earnings, and (imputed) family income. The results paint a coherent picture which suggests that high sex ratios in the early $20^{\text {th }}$ Century improved female marriage prospects, reduced female labor force participation, and tilted the balance of household bargaining power towards women more generally. Estimates for families with children also suggest that higher sex ratios led to increased marital stability and higher income in families with children. Before presenting the empirical

${ }^{1}$ Sex ratios were .91 in Washington, and .93 in New York, about 89 percent of the expected ratio at birth.

${ }^{2}$ Becker [1973] and Grossbard-Shechtman [1984] proposed an autonomous change in sex-selective migration as a "thought experiments" useful for assessing the implications of an exogenous change in sex ratios. 
results, the next section discusses theories in which sex ratios affect social and economic conditions, and briefly reviews earlier studies of the sex ratio question.

\section{Background}

\section{A. Theoretical Framework}

Becker's [1981] model of marriage and family formation provides a simple framework for interpreting the effects of changing sex ratios. The Becker model takes the goal of marriage to be joint production, broadly defined (e.g., income and/or the monetized value of reproductive potential). Changes in sex ratios are predicted to affect marriage rates and family income. In particular, an increase in the sex ratio increases the demand for wives, thereby increasing female marriage rates and the income of women, while reducing male income and transferring part of the surplus generated by marriage from men to women. Becker speculates that changes in income associated with changing sex ratios might be observed in spousespecific data on consumption. Changes in individual leisure may also be observed through labor supply and, in any case, there should be a negative effect of income on labor supply. These considerations suggest female labor supply should fall and male labor supply rise when sex ratios increase.

An increase in transfers from men to women, including an increased willingness to make legally binding commitments through marriage, is another way in which higher female incomes may be captured in high sex-ratio societies. This idea is echoed in Wilson's [1997] thesis that low sex ratios among poor blacks contribute to high rates of out-of-wedlock childbearing, low marriage rates, and low levels of male parental investment. A related implication of Becker's theory is that men have an incentive to become more "efficient" (i.e., attractive to potential wives) in markets where women have a high marginal product in marriage. Since the marginal product of wives increases when sex ratios increase, this implies a positive correlation between sex ratios and male investment in earnings potential and other characteristics that contribute to efficiency.

Becker notes that polygyny has been common in human history while polyandry is almost non- 
existent. He speculates that this is due to a lower marginal contribution of additional husbands to household production than of additional wives. While clearly true for household objectives defined in terms of reproductive potential, this is less obviously the case for earnings or other aspects of household production. Assuming polygyny is the relevant manifestation of polygamy, the Becker model predicts that an increase in sex ratios will lead to a decline in the number of polygynous unions. This is because increasing the number of men increases the demand for first wives, who are postulated to have a higher marginal product than co-wives. Polygyny is illegal in the United States, but predictions in this regard may nevertheless be relevant if we replace polygyny with concepts like the number of partners or "serial monogamy".

Attempting to integrate the theories of marriage and labor markets more fully, Grossbard-Shechtman [1984] argued that spouses can be viewed as providing a type of home-production for which there are market substitutes. ${ }^{3}$ In her framework, an increase in sex ratios increases the demand for wives' spousal labor. This increases the shadow wage for home production, thereby reducing female labor force participation outside the home. In principle, changing wages for home production may affect labor supply by unmarried women as well, since unmarried women in a high sex ratio environment should respond to the increased demand for spousal labor by marrying sooner and investing less in skills valued in the labor market outside the home.

Finally, a recent literature analyzes household bargaining and the distribution of resources within families. For example, Chiappori, Fortin, and Lacroix [2001] outline a model of household decision-making that presumes bargains are efficient. Sex ratios are an exogenous "distribution factor" in their set-up, affecting spouses' bargaining strength. In particular, high sex ratios improve women's bargaining position within households, as well as in the marriage market. An implication of this framework is that high sex ratios benefit children, since women are more likely than men to shift household resources towards children (see, e.g., Thomas, 1990; Duflo, 1999). The Becker, Grossbard-Shechtman, and bargaining theories have similar implications, with the notion of increased bargaining power for women a common theme.

\footnotetext{
${ }^{3}$ See also Heer and Grossbard-Shechtman [1981], Grossbard-Shectman and Neideffer [1997].
} 


\section{B. Previous Research on Sex Ratios}

Most of empirical research on sex ratios looks at effects on marriage. Anecdotal and quantitative evidence on the relationship between sex ratios and marriage rates indeed suggests a strong link. Guttentag and Secord [1983] recount a number of historical episodes when sex ratios were high, typified by the story of an observer who noted that in male-dominated colonial America, lack of a dowry was no handicap for a woman seeking marriage. High sex ratios were also reflected in the match quality a woman could expect, as noted by a Maryland plantation owner (p. 117): "Maid servants of good honest stock may choose their husbands out of the better sort of people."

Two of the earliest empirical studies linking sex ratios with marriage rates are Groves and Ogburn's [1928] analysis of 1920 Census data for US cities, and Cox [1940], who looked at the connection between sex ratios and marriage for blacks in the 1930 Census. Both of these studies found that increasing sex ratios increase the marriage rates of women, with little or no effect on men. Easterlin [1961] noted the decline in marriage and sex ratios among the foreign born in the 1920s, and he suggested the two phenomena were linked. Frieden [1974] presented a cross-section analysis of sex ratios in states and counties in the 1960 Census. Grossbard-Shectman [1985, 1993] studied links between sex ratios and female labor supply in US cities, as well as effects on marriage rates.

Other studies of sex-ratio effects include South and Lloyd [1992] and South and Trent [1988], who looked at marital status, childbearing, labor force participation and sex roles and Jemmot, Ashby, and Lindenfield [1989], who studied sex ratios and romantic commitment on college campuses. More recently, Chiappori, Fortin, and Lacroix [2001], one of the few studies to include men, estimate the relationship between sex ratios and labor supply across states for couples in the Panel Survey of Income Dynamics. The consequences of changing sex ratios in the developing world have also received attention; an example is Rao [1973], who documented a negative relationship between dowries and the relative supply of men. A potential problem with all of these studies is omitted variables bias and reverse causality in the relationship between sex ratios and measures of economic and social conditions. Changes in sex ratios by ethnic group may 
provide a better experiment for the study of sex ratio effects than regional differences.

\section{Immigration and Sex Ratios from 1880-1930}

Almost 28 million immigrants came to the US in the 50 years beginning in 1880 . Arrival rates crested in the 1880s, and then peaked again with a wave of 15 million immigrants arriving in the 1910s and 1920s (US Bureau of the Census, 1975). Effective restrictions on European immigration were first imposed in 1921, when Congress established immigration quotas. The 1921 law set up a comprehensive system of national-origin quotas. This was soon followed by the 1924 Johnson-Reed Act, which set quotas at 2 percent of nationality populations in the 1890 Census. The 1924 Act is generally viewed as having ended the era of mass immigration, and the quota system for non-refugees was not substantially revised until 1965 . After 1924, however, immediate family members of US citizens (including immigrants), as well as some refugee groups, could obtain immigrant visas. ${ }^{4}$

The average sex ratio among immigrants arriving from 1820-1920 was about 1.5 (Hutchinson, 1956). Fluctuations in immigrant sex ratios were determined by a number of forces, including home country conditions and the goals and fortunes of immigrants in the US labor market. For example, Jewish families fled pogroms in Russia and fewer men came to the US during the Great Depression (see, e.g., Tyree and Donato, 1985). But changes in immigration policy were probably the most important force changing sex ratios in the first half of the $20^{\text {th }}$ Century. In particular, Hutchinson [1956, p. 18] notes that the quota acts of the early 1920s: "granted quota preferences or nonquota status to relatives of immigrants residing in the United States, favored a higher proportion of females among new arrivals; and immigration during the refugee period became more a movement of family groups and less a movement of males seeking employment." Thus, the quota acts induced large-scale exogenous variation in both the number and sex-

${ }^{4}$ A 1927 modification of Johnson-Reed introduced a national-origins provision that set quotas using 1920 Census counts; total European immigration was still capped at about 150,000. 
composition of new arrivals beginning in the 1920s. ${ }^{5}$ I exploit this variation by matching variation in immigrant sex ratios by ethnic group from 1910-40 with the social and economic conditions of second generation individuals in the same ethnic groups.

\section{Census Data and Descriptive Statistics}

\section{A. The IPMUS Samples}

The data used here come from the 1910, 1920, and 1940 Census IPUMS files (Ruggles and Sobek, 1997). The 1920 Census contributes the most observations since this is a 1 -in-100 sample. The 1910 IPUMS data set is a 1-in-250-file, while sample-line (long-form) respondents from the 1940 Census constitute an approximate 1-in-330 sample. A number of variables have been recoded in the IPUMS to increase comparability across census years. The 1910, 1920 and 1940 Censuses are among the more similar in the IPUMS, though some economic variables in the 1940 data set still differ importantly from similarly-named variables in 1910 and 1920 (Ruggles, 1991).

My extract combines micro data on the second generation (children of the foreign born) with information on sex ratios in the first generation (immigrants). The second-generation samples include men aged 20-35 and women aged 18-33, the age groups where marriage rates are highest. Children of married couples in these age groups are also highly likely to be living with their parents and therefore observed in the same household. First generation sex ratios were constructed by dividing the number of immigrant men aged 20-35 by the number of immigrant women aged 18-33 for each ethnic group and year. The age groups are staggered because men tend to marry older women. ${ }^{6}$

${ }^{5}$ Hutchison (1956) comments on the forces behind changing sex ratios in a discussion of a table showing sex ratios by country of origin from 1920 to 1950 . The appendix table shows similar statistics and exhibits a similar pattern. Sex ratios declined more sharply after the quota acts for European groups affected by the quotas than for groups from North America who were not affected. Hutchison (pp. 18-19) singles out Mexicans and Canadians as having relatively stable sex ratios, and notes the large decline among Eastern European groups.

${ }^{6}$ The expected age at first marriage was about 23 for women and 26 for men in 1920 (Haines, 1996). I used a two-year age gap to calculate sex ratios to reduce the likelihood of including the parents' of second generation respondents in first-generation sex ratios. With a two year gap, the oldest man in the first generation 
The ethnic groups in the sample were chosen to match the ten most important turn-of-the-century immigrant groups, plus an $11^{\text {th }}$ catchall group not elsewhere classified (NEC). My coding of these groups is based on Pagnini and Morgan [1990, p. 407], with the addition of Mexicans, many of whom arrived after the revolution of 1917. The resulting groups are: British, Irish, Italian, Canadian, Mexican, Nordic countries (Scandinavia plus Iceland), German-Austrian, Hungarian-Romanian, Russian-Polish, and Central and Eastern European Jews. The German-Austrian, Hungarian-Romanian, and Russian-Polish groups exclude Jews, who are lumped together regardless of country of origin. An appendix provides a more detailed description of how the ethnic groups were coded.

\section{B. Descriptive statistics}

Descriptive statistics for first and second generation respondents, as well as natives the same age, are shown in Table I. The second generation columns include statistics for those of both dual foreign and mixed foreign parentage. Over 40 percent of the 1910 and 1920 samples were of "foreign stock", i.e., foreign born or second generation. This fell to about 30 percent in 1940.

Men in every group and year were less likely to be married than women. The table also shows marked differences in marriage rates by nativity. In 1910, only 47 percent of second generation women aged 18-33 were married while 59 percent of native women were married. Female marriage rates in all groups increased later, but remained lower for the second generation than for natives or the foreign born. Low marriage rates in the second generation have been noted previously by, among others, Groves and Ogburn [1928], Haines [1996] and Landale and Tolnay [1993]. ${ }^{7}$ Also noteworthy is the prevalence of extended households for the US born. This can be seen in the high proportion of men and women in the native and second generation samples still living with their mothers. Single children, especially daughters, were much

sample, aged 35, is only 17 years older than the youngest woman, aged 18, in the second generation sample.

${ }^{7}$ A comparison of first generation marriage rates in 1920 with second generation marriage rates in 1940 also shows low marriage rates for the children of immigrants. 
less likely to leave home in the first half of the $20^{\text {th }}$ Century than they are today.

Economic variables in the analysis include labor-force status and imputed income based on occupation codes. The imputed income variable was constructed from a regression relating the IPUMS coding of median 1950 income by occupation to wage and salary earnings in the 1940 Census. The appendix provides a detailed description of the imputation, which is essentially an age- and sex-specific re-scaling of the underlying 1950 occupation codes. The labor force status variable is an indicator for whether the respondent reported an occupation. This corresponds to the definition of labor force participation used in the 1910 and 1920 Censuses. ${ }^{8}$ In addition to these two individual-level variables, I also constructed a family income score by summing the imputed income of everyone aged 14-69 in the same family. Of course, this measure fails to reflect the true nature of family income pooling. Tentler [1981] discusses the home economy in this period, and notes that working daughters living at home transferred almost all wages to their mothers. Working sons, in contrast, were more likely to keep part of their wages, while paying for room and board once they were adults.

The descriptive statistics show that labor force participation rates and income scores were much lower for women than for men in every year in the sample, though many young women worked during this period. The bulk of female labor force participation was by unmarried women, and married women typically quit their jobs or were fired as a consequence of explicit or understood marriage bars (Goldin, 1990).

Imputed income is higher for immigrants than for natives, but this reflects the fact that immigrants were much less likely than natives to work in agriculture, and more likely to live in big cities and the relatively high-wage Northeast and Midwest. Adjusting for these characteristics shows immigrants with a clear income disadvantage, though smaller than the wage gap reported by Borjas [1994] for an older sample in 1910. The fact that the children of immigrants had higher income than natives is not explained by occupation, region of residence, or age differences. Chiswick [1977] similarly found a modest earnings

\footnotetext{
${ }^{8}$ The 1940 census included a more modern labor force question, but this does not match the variable used in earlier years. In practice, the two measures of participation in 1940 are almost identical.
} 
advantage for second generation men in 1970 Census data.

The ethnicity and sex distribution of the foreign stock are described in Table II for the sample of men and women aged 18-35. The largest immigrant group in the 1910 sample was the German/Austrians. In 1920, the Russian/Polish group was largest, while in 1940, the Canadians were most numerous among young immigrants. Combining the Russian/Polish group with the Jews, most of whom were Russian, produces the largest group in 1910 and 1920. Thus, Eastern Europeans and Italians came to outnumber the veteran groups from Germany and Austria, Nordic countries, and the UK in this period. Not surprisingly, the ethnicity distribution in the second generation is more persistent than the ethnicity distribution of immigrants, though by 1940 , Italians made up the largest second-generation group. An important factor affecting the number and ethnicity mix of immigrants in 1920 was World War I, which reduced the flow from most combatant countries from 1914 to 1919 , but probably increased it immediately after.

Sex ratios by ethnicity reflect the fact that most immigrants groups were disproportionately male, though there is marked variation across groups and over time. For example, Italian immigrants were predominantly male, while Irish immigrants were disproportionately female. All immigrant groups except the Irish and Canadians were predominantly male in 1910 and 1920. Between 1910 and 1940, immigrant sex ratios declined for every ethnic group except the Irish, so that by 1940 sex ratios in many groups were close to, or even below, 1 . The decline in immigrant sex ratios partly reflects the impact of the quota acts. In addition to the fact that men arrived first, migration of family groups favored women since co-residence and dependency rates were higher for women than men. The fact that sex ratios in 1940 actually fell below 1 for some groups also reflects return migration. Administrative arrivals data collected by US immigration authorities (discussed in more detail in the appendix) show more balanced sex ratios for the 1920-1929 period than the 1940 Census, with ratios above 1 in all but three groups, and the lowest ratio at .83 .

Immigrant sex ratios affected marriage prospects in the second generation because of endogamy. The importance of endogamy is documented in Table III, which reports the distribution of spouses' ethnicity. In particular, the table shows the proportion of married men and women who had married natives, married 
endogamously (i.e., with a first or second generation spouse in the same ethnic group), and married people of other foreign stock. The ethnicity distribution of spouses is tabulated separately for natives, the second generation, and the foreign born.

The first row of Table III shows that 85 percent of natives married other natives. In contrast, the proportion marrying natives was much lower in every second generation ethnic group, and lower still among the foreign born. Endogamy in the first generation was partly due to the fact that many immigrants arrived married. But endogamy in the second generation reflects strong preferences for within-group marriage. Over 85 percent of Italian and Jewish women in the second generation married in the same group, and withingroup marriage was common even among the children of English-speaking immigrants from Ireland and the UK. For example, only 53 percent of second generation British women married natives. Interestingly, endogamy rates were as high for the second-generation NEC group as for many of the more narrowly defined groups. The NEC classification is therefore a useful addition to the ethnic taxonomy. ${ }^{9}$

Table III also shows that within-group marriage was typically more common for second-generation women than second-generation men. Endogamous marriage rates for women exceed those for men by at least two percentage points in every second-generation group except the British, Irish, Canadians, and Nordic. Among the foreign born, however, endogamy was about equally likely for men and women.

\section{Sex-Ratio Effects on Adults}

\section{A. Graphical Analysis}

The empirical strategy used here exploits changes in immigrant sex ratios between 1910 and 1940, focusing on the effects of this variation on the second generation. While the underlying microdata sample includes hundreds of thousands of observations, this strategy can also be understood as an analysis of averages for 33 year-ethnicity cells (11 ethnicity groups $\times 3$ years). Looking at sex-ratio effects on marriage,

\footnotetext{
${ }^{9}$ The largest group of NEC foreign born in the sample was from Greece (18 percent), followed by Czechoslovakia (13 percent), France (7 percent), Portugal (6 percent), and Spain (5 percent).
} 
for example, each cell contains the marriage rate of second-generation respondents in a particular ethnic group and year, linked with the sex ratios of young immigrants of the same ethnicity in the same year.

The analysis of ethnicity-year cells is illustrated in Figure 1. This figure plots the cross-sectional relationship between immigrant sex ratios and the proportion ever marriage by second generation ethnicity, after removing year effects (i.e., the average sex ratio in each census year) and regression-adjusting for the number of immigrants in each ethnic group. ${ }^{10}$ The figure shows that higher sex ratios are associated with higher marriage rates for women. Marriage rates for men, in contrast, are widely dispersed around the regression line, which has a slope not significantly different from zero.

Part of the relationship between sex ratios and marriage rates may be either due to, or masked by, ethnicity-specific characteristics that are transmitted across generations. For example, immigrants from Southern Italy and Eastern Europe, groups with high sex ratios, were mostly poor and uneducated. These characteristics were, to some extent, inherited by the Italian and Eastern European second generation. Low education of women is usually associated with earlier marriage, while poverty may delay marriage, so the causal effect of changing sex ratios could be biased either up or down in the ethnic cross-section. Some of these biases may be eliminated by removing ethnicity-group fixed effects.

Figure 2 plots the relationship between sex ratios and marriage rates after removing ethnicity-group fixed effects. This relationship reflects the association between the change in second-generation marriage rates and the change in sex ratios, where changes are measured from census to census. Figure 2 provides a visual representation of the identification strategy used here, and shows a much tighter relationship around the regression line, reflecting the fact that much of the variation in marriage rates across ethnic groups is captured by the ethnicity fixed effects, especially for women. The slopes in Figure 2, .15 for women and .05 for men, are about twice as large as the corresponding slopes in Figure 1, suggesting omitted ethnicity

\footnotetext{
${ }^{10}$ The figure plots residuals from a regression of sex ratios and the average proportion ever-married on year dummies and the $\log$ of the number of immigrants in the cell. The figures also show regression lines and confidence intervals for predicted means. Cells with fewer than 500 observations were not plotted.
} 
effects bias the slope in Figure 1 downwards.

Most of the previous work on sex ratio effects uses regional variation. For example, Chiappori, Fortin, and Lacroix [2001], look at sex ratios in a cross-section of US states in the 1990 Census. For comparison with the ethnicity strategy, Figure 3 shows the cross-sectional relationship between marriage rates and sex ratios by state for US-born men and women aged 18-35 in the 1910, 1920, and 1940 Censuses. As before, the plot adjusts for year effects and population size (in this case, native population by state and year). The state plot shows a larger effect of sex ratios on women's marriage rates than the ethnicity plots, with a sharply negative effect for men. The results of removing state fixed effects are shown in Figure 4. The estimate for women falls to .16, comparable to the ethnicity estimate of .15 in Figure 2. The results for men are still sharply negative, however. This suggests there may be some bias in estimates that use regional variation in sex ratios, at least for men. Estimates using using variation by state and year may be biased downwards by the fact that young single men were especially likely to migrate in search of work opportunities in the American West.

\section{B. Empirical Framework}

The estimation framework controls for individual characteristics as well as ethnicity and year effects. Because the size of immigrant flows was changing at the same time that immigrant sex ratios were changing, the regression used to construct the estimates also includes the number of immigrants in each group. The estimating equation for second-generation individual $\mathrm{i}$, in ethnic group $\mathrm{j}$, observed in census year $\mathrm{t}$, is

$$
\mathrm{y}_{\mathrm{ijt}}=\mathrm{X}_{\mathrm{i}}^{\prime} \gamma_{0}+\alpha \mathrm{R}_{\mathrm{jt}}+\beta \ln \mathrm{N}_{\mathrm{jt}}+\gamma_{\mathrm{at}}+\delta_{\mathrm{j}}+\varepsilon_{\mathrm{ijt}}
$$

where foreign-born sex ratios, $R_{j t}$, and immigrant counts, $N_{j t}$, vary by ethnicity and year. The covariates $X_{i}$ include a pair of dummies indicating type of mixed parentage (mother-only, father-only), $\gamma_{\mathrm{at}}$ is an age effect for each census year, and $\delta_{\mathrm{j}}$ is an ethnicity effect. The list of dependent variables, denoted $\mathrm{y}_{\mathrm{ij}}$, includes demographic and economic outcomes such as marital status, labor force participation, and income.

The variable $R_{j t}$ is the ratio of the number of men aged 20-35 to the number of women aged 18-33 
by year and ethnicity group, and $\ln \mathrm{N}_{\mathrm{jt}}$ is the $\log$ of the total number of immigrants in these age groups. I also explore a specification where these variables are calculated for the foreign stock (immigrants+second generation) instead of the foreign born. In both specifications, equation (1) can be rationalized by a production function that aggregates the number of men and women in the marriage pool into a single causal factor affecting outcomes. The production function links sex ratios directly to outcomes, side-stepping the need to derive effects from separate coefficients on numbers of male and female immigrants.

To describe this model further, let $\mathrm{p}_{\mathrm{jt}}$ be the proportion of men among immigrants from ethnic group $\mathrm{j}$ in year $\mathrm{t}$ in the relevant age groups, and note that $\mathrm{R}_{\mathrm{jt}}=\mathrm{p}_{\mathrm{jt}} /\left(1-\mathrm{p}_{\mathrm{j} t}\right)$. Suppose that the size and sex composition of immigrant flows interact to produce marriages and other outcomes through a single variable, $\mathrm{Z}_{\mathrm{j} \text {, }}$, defined by,

$$
\mathrm{Z}_{\mathrm{jt}} \equiv \ln \left(\mathrm{f}\left[\mathrm{p}_{\mathrm{jt}}, \mathrm{N}_{\mathrm{jt}}\right]\right)=\ln \left(\mathrm{f}^{*}\left[\mathrm{p}_{\mathrm{jt}} \mathrm{N}_{\mathrm{jt}},\left(1-\mathrm{p}_{\mathrm{jt}}\right) \mathrm{N}_{\mathrm{jt}}\right]\right)
$$

Finally, suppose that the function, $\mathrm{f}$, is given by

$$
\mathrm{f}\left[\mathrm{p}_{\mathrm{j} t}, \mathrm{~N}_{\mathrm{jt}}\right]=\theta_{\mathrm{j}} \mathrm{R}_{\mathrm{jt}}{ }^{\varphi} \mathrm{N}_{\mathrm{jt}}{ }^{\psi} .
$$

This allows for constant returns to scale in matching (as in, e.g., Berman [1997]) or increasing returns. ${ }^{11}$ Because $\log \left(\mathrm{R}_{\mathrm{jct}}\right) \approx \mathrm{R}_{\mathrm{jt}}-1$ (with the approximation exact at $\mathrm{p}_{\mathrm{jt}}=.5$ ), the Cobb-Douglas formulation is equivalent to model (1).

The variable $\mathrm{R}_{\mathrm{jt}}$ is constructed from the sex distribution of immigrants in the Census. This "ambient sex ratio" is subject to measurement error and is affected by return migration, as well as immigrant arrivals. Return migration seems likely to be more responsive to local (US) economic conditions than immigrant arrivals. ${ }^{12}$ To reduce the likelihood of bias from measurement error or economically-motivated return

\footnotetext{
${ }^{11} \mathrm{~A}$ more flexible but still linear specification allows the number of men and women to have separate effects instead of a single coefficient on the sex ratio. Suppose$$
\ln \mathrm{f}^{*}\left[\mathrm{p}_{\mathrm{jt}} \mathrm{N}_{\mathrm{jt}},\left(1-\mathrm{p}_{\mathrm{jct}}\right) \mathrm{N}_{\mathrm{jt}}\right]=\varphi_{\mathrm{m}} \ln \left(\mathrm{p}_{\mathrm{jt}}\right)+\varphi_{\mathrm{w}} \ln \left(\left(1-\mathrm{p}_{\mathrm{jt}}\right)\right)+\psi \ln \left(\mathrm{N}_{\mathrm{jt}}\right) .
$$

The three regressors in this formulation are conceptually distinct, but their effects cannot be separately determined in practice (similar to age, period, and cohort effects). Imposing the restriction $\varphi_{\mathrm{m}}=-\varphi_{\mathrm{w}} \equiv \varphi$ leads to (2).

${ }^{12}$ Willcox (1931, p. 91) estimated that roughly 3/4 of immigrants arriving between 1890 and 1920 were permanent.
} 
migration, I computed instrumental variables (IV) estimates as well as OLS estimates of the effect of sex ratios. The instrumental variables set-up treats $\mathrm{R}_{\mathrm{jt}}$ and $\ln \mathrm{N}_{\mathrm{jt}}$ as endogenous in equation (1), with instruments derived primarily from the Ferenczi and Willcox [1929] series on immigrant aliens admitted by sex, year, and nationality. Arrivals data are for ethnicity group $\mathrm{j}$ in the 10 years preceding $\mathrm{t}$ for which data are available (1900-1909 for the 1910 Census, 1910-1919 for the 1920 Census, and 1920-29 for the 1940 Census). The data appendix discusses the scheme used to match the arrivals data with census data.

The first stage estimates are reported in Panel A of Table IV. ${ }^{13}$ There are two excluded instruments in each equation, the arrivals ratio and the immigrant count. The first four columns of the table report estimates of models where the census sex ratio and immigrant count are for the foreign born, while columns 5-8 show comparable estimates using analogous variables for the foreign stock. Not surprisingly, the arrivals data are more highly correlated with the characteristics of the foreign-born than with the characteristics of the foreign stock. For example, the estimates indicate that a .1 increase in the arrivals ratio increased the foreign born sex ratios by .053 , while the same change would have increased the foreign stock sex ratio by .036 .

Panel B of Table IV reports a set of first-stage estimates for an older cohort composed of women aged 34-48 and men aged 36-50. These estimates provide a check on whether the arrivals measures are most strongly correlated with the size and sex composition of the younger, more "marriage-prone" age group. The estimates confirm that the association between the characteristics of arrivals and the foreign born population is much weaker for the older cohort. Sex ratio effects on the older cohort are less than half as large as for the younger cohort, while the relationship between numbers of arrivals and the size of the foreign-born population is less than one-quarter the size of the corresponding effect on younger cohorts.

\footnotetext{
${ }^{13}$ The standard errors reported in this table and elsewhere in the paper were adjusted for state-year clustering using the formula in Moulton [1986].
} 


\section{C. $\underline{\text { OLS and IV Estimates }}$}

The OLS estimates for women suggest that increasing sex ratios had a modest but precisely measured effect on marriage probabilities. This can be seen in Panel A of Table V, which reports estimates for the effect of sex ratios on variables describing family structure. An increase in sex ratios from 1 to 1.25 (the sample mean for immigrants) is estimated to have raised the probability of marriage by a little over 3 percentage points, or about 6 percent of the average marriage rate in the sample. This is also about the size of the immigrant-native difference in marriage rates. Other OLS estimates in the table show that sex ratios had slightly smaller effects on childbearing and the probability of living in an extended household [as measured by an indicator for maternal co-residence). Family size is also predicted to decline as sex ratios increase, probably because extended households were larger than the households formed by the newly married.

As noted earlier, OLS estimates of sex ratio effects are potentially biased by measurement error and return migration. In practice, the 2 SLS estimates of sex ratio effects in Panel A of Table V are mostly close to the OLS estimates, though generally somewhat larger. One noteworthy difference between 2SLS and OLS in this context is the fact that the 2 SLS estimates of immigration-size effects (i.e., the coefficient on $\ln \mathrm{N}_{\mathrm{jt}}$ ) are almost all smaller than OLS and in many cases insignificant. This is important because weak immigration effects suggest that it really is the sex ratio that "does the work" in equation (1).

Columns (4) and (5) in the table report estimates of an alternative model where variables for the foreign stock replace variables for the foreign born. This specification is motivated by the assumption that the marriage market is unified for all foreign stock of a given ethnicity. Most of the variation in foreign stock sex ratios comes from variation for the foreign born, but the two measures are not identical. OLS estimates of the effects of foreign stock sex ratios are larger than the corresponding OLS estimates of the effect of foreign born sex ratios. Because the first stage effects on the foreign stock sex ratio are smaller than the corresponding effects on the foreign born sex ratio, the 2SLS estimates of the effect of foreign-stock sex ratios are also larger. The differences across columns are not dramatic, however, and the choice of 
endogenous variable is not key for the interpretation of results.

Sex ratios affected economic outcomes for women, probably as a secondary consequence of the relationship between sex ratios and marriage. This is documented in Panel B of Table V, which reports estimates of effects on labor-force status and measures of individual and family income. Both the OLS and 2SLS estimates show a well-determined negative association between sex ratios and labor force participation. These estimates are about $2 / 3$ as large as the estimated sex ratio effects on marriage, implying that each percentage point increase in marriage induced by increased sex ratios is associated with $2 / 3$ of a percentage point reduction in labor force participation. The participation effects are likely explained by the fact that women in this period typically left work when they married (Goldin, 1990). It should be noted, however, that some of the apparent labor-force effect is likely due to a reluctance among married women to report they were working. ${ }^{14}$ Sex ratios are similarly associated with lower individual incomes for women, though effects on log wages are small and mostly insignificant.

The remaining income variables describe economic conditions for couples and families. The first, spouse's income score, measures the (imputed) income contributed by spouses. This equals zero for women or men without a spouse present (whether married or not), and can be thought of as measuring the increase in the probability of marriage times average spouse income. The fact that sex ratios are associated with an increase in the combined husband and wife income score, a result also reported in the table, indicates that the income contribution from husbands more than offset the decline in women's earnings caused by marriage.

Another interesting result in Table $\mathrm{V}$ is the strong negative association between sex ratios and total family income. This is likely explained by the fact that many newly married women set up their own households, though other family composition effects may have played a role. The notion that family composition effects are behind the decline in family income is supported by the result showing no relationship between sex ratios and family income per person aged 14-69 (these are the people whose income

\footnotetext{
${ }^{14}$ Goldin [2000] notes that labor-force participation rates among married women before 1940 were almost certainly higher than reported, though still very low.
} 
was counted to compute the family income score). The negative relationship between sex ratios and family size in Panel A is also consistent with a change-in-marital-status explanation for the family income effects. The reduction in adult family size is larger than the reduction in total family size, probably because the reduction in total size was moderated by an increase in childbearing among newly married women. Other factors connecting sex ratios and family structure are discussed following a review of the results for men.

As in Figure 2, Table VI shows positive effects on marriage rates for men, again much smaller than the corresponding marriage effects for women. The OLS estimates of the effect of sex ratios on male marriage rates are not significant, but the corresponding 2SLS estimates show a significant .036 increase in the probability men had ever married. These estimate differ from the estimate in Figure 2 primarily because the figure excludes small ethnicity-year cells. Models that treat the foreign stock sex ratio as endogenous generate a 2 SLS estimate of .048 for the effect of sex ratios on the probability men ever married. The effects on the likelihood living with own-children are of a slightly smaller magnitude, suggesting they might be explained by the marriage effects.

The positive association between sex ratios and marriage rates for women can be explained by the increased availability of potential mates. A positive relationship between sex ratios and male marriage probabilities is more surprising, however, since an increase in the number of men might have led to a shortage of potential spouses. On the other hand, there were still enough potential spouses to go around since roughly half of the women in the age groups studied here were not married. Moreover, the theoretical framework outlined above suggests an alternative mechanism driving marriage effects. In this framework, increasing sex ratios increase women's bargaining power in the marriage market. Increased female bargaining power could have led men to make stronger emotional and financial commitments to women in the form of marriage.

In contrast with the estimated effects on women's economic outcomes, Panel B of Table VI shows no relationship between sex ratios and male labor force status or individual income. This is not surprising given the small effects on male marriage rates in Panel A. On the other hand, there is a small, marginally 
significant (at the 10 percent level) positive association between sex ratios and log wages. This suggests that men may have obtained or retained better jobs when sex ratios were higher. The wage effect, while small, is still probably too large to be explained by changes in marital status alone. This increase in wages may nevertheless reflect greater investment in education or on-the-job training when conditions in the marriage market became more competitive. This corresponds to Becker's notion of male "efficiency".

In addition to small effects on marriage, childbearing, and wages, Table VI shows that sex ratios are correlated with other indicators of family structure for men. Increasing sex ratios reduced the probability of maternal co-residence, though the estimate of this effect is less precise and considerably smaller than the corresponding estimate for women. Sex ratios are also negatively correlated with men's family size and family income, and positively correlated with the likelihood that male respondents were heads of household. The negative effects on total family size for men exceed those for women, probably because for women, reductions in the number of co-resident adult family members were offset by increases in the number of children due to higher marital fertility. Effects on the number of co-resident family members aged 14-69 are negative and similar in magnitude for men and women.

The effects of sex ratios on male marriage rates are too small to account for the estimated changes in family structure associated with increasing sex ratios. This suggests that first generation sex ratios affected the family environment for reasons other than respondents' own marriage prospects. An additional channel for sex ratio effects on men is the fact that changes in female marital status would have been experienced by second generation men through co-resident sisters and aunts. For example, changes in female marital status would have pulled sisters and aunts out of extended families into smaller households, reducing everyone's average family size, and providing additional opportunities for family co-residence and male headship outside the parents' household.

A second factor linking first-generation sex ratios and family structure is the difference in the extended-family co-residence propensities of men and women. Women generally had higher co-residence propensities than men, and sex differences in co-residence propensities were especially large for unmarried 
sisters (Ruggles, 1987). Thus, declining sex ratios would have increased the proportion of immigrants likely to join established households with a first generation head. Reinforcing this is the fact that declining sex ratios were caused in part by immigration policies that favored the relatives (both male and female) of those already here. Finally, the addition of (mostly male) unrelated boarders may have increased the opportunity cost of co-residence for male children who could support themselves in independent living arrangements. Ruggles [1987] and others have noted that boarders were commonly found in extended-family households during this period.

The association between sex ratios and family size raises the question of whether sex ratio effects on economic outcomes were due solely to changes in the marriage market. One possible direct consequence of smaller families may have been a reduced economic burden on first-generation heads and spouses. But the extended family members affected by sex ratios were mostly working, so their presence in the household could have been a plus. In any case, however, changes in numbers of co-resident siblings and aunts and uncles seem unlikely to have had lasting economic consequences for the second generation, especially once the latter left the head's family. This view is supported by the fact that income per-working-age family member is not associated with sex ratios for either women or men. In contrast, the two income variables directly linked to marital status, the spouse and couples' income scores, show a strong relationship with sex ratios. It is also worth noting that while the modest positive effect of sex ratios on log wages for men may be due to a selection effect associated with male-biased migration, Borjas [1990] found that those who immigrated as part of a family unit (i.e., in an environment characterized by low sex ratios) were more skilled and had higher earnings than persons who migrated on their own.

\section{Specification Checks}

The marriage market story has a number of implications than can be checked. First, if sex ratios affected outcomes primarily through the marriage market, instead of, say, other changes in household composition, sex ratio effects should be larger where endogamy is more important. A simple check on the 
marriage-market thesis can therefore be had by interacting the sex ratio with group-specific endogamy rates. This strategy leads to an equation of the form

$$
\mathrm{y}_{\mathrm{ijt}}=\mathrm{X}_{\mathrm{i}}^{\prime} \gamma_{1}+\alpha_{10} \mathrm{R}_{\mathrm{jt}}+\alpha_{11} \mathrm{R}_{\mathrm{jt}} \mathrm{m}_{\mathrm{j}}+\beta_{1} \ln \mathrm{N}_{\mathrm{jt}}+\gamma_{\mathrm{at}}+\delta_{\mathrm{j}}+\varepsilon_{\mathrm{ijt}},
$$

where $\mathrm{m}_{\mathrm{j}}$ is the proportion of endogamous marriages in ethnic group $\mathrm{j}$ in the 1910 Census. The estimation in this case uses only the 1920 and 1940 Censuses since endogamous marriage is an outcome that was potentially affected by sex ratios. The effect of sex ratios at the mean endogamy rate is $\alpha_{10}+\alpha_{11} \bar{m}_{\mathrm{j}}$, where $\overline{\mathrm{m}}_{\mathrm{j}}$ is the proportion of second generation respondents married to someone from the same (first or second generation) ethnic group in the 1910 Census (.45 for women and .42 for men).$^{15}$

Most of the results for women support the notion that sex ratio effects are larger when endogamy is more prevalent. This can be seen in Table VII, which reports estimates of $\alpha_{10}, \alpha_{11}$, and the effect at the mean. OLS and 2SLS estimates of $\alpha_{11}$ for effects on marriage are positive and significant, while the interaction terms for maternal co-residence, effects on labor force participation, and individual income, are negative and significant. The interaction terms in models for couple income are positive, as is the effect at the mean. One difference between results from models with interaction terms and those without is that while the earlier results for this outcome were negative, the interaction term for the effect on family income is positive.

For men, OLS estimates of models with endogamy interactions show no relationship between sex ratios and marriage. But 2SLS estimates of the same relationship show a marginally significant positive interaction term. This echoes the difference between the OLS and 2SLS results for male marriage rates in Table VI. The 2SLS estimate of the interaction term for effects on living with own children (not reported in the table) is also positive and significant, suggesting that this outcome too is related to the impact of high sex ratios on the marriage market. Interestingly, the 2SLS estimate of the interaction term for effects on male labor supply is also positive and significant, so that increasing sex ratios are predicted to increase labor force

\footnotetext{
${ }^{15}$ Endogamy rates are defined as the probability of marriage (with spouse present) to a person from the same ethnic group, conditional on being married.
} 
participation when endogamy rates are high. On the other hand, there is no significant effect of sex ratios on log wages in these models.

Another check on the marriage-market interpretation of the results in Tables V and VI looks for sex ratio effects when the ratios are defined for an older sample no longer in the marriage-prone years. The idea here is that household composition and other effects are likely to have been at least as strong when sex ratios are defined for those too old to provide mates for men and women in the sample age group. I implemented this idea by adding sex ratios for an older sample of first-generation men and women to equation (1). The results generally support the view that sex ratios for younger first-generation respondents -- and hence marriage-related factors -- provided the most important links between sex ratios and outcomes, though they are less clear-cut for men than for women. For more details, see my working paper (Angrist, 2000). ${ }^{16}$

\section{Results for the Third Generation}

The estimates for women suggest that higher sex ratios led to higher marriage rates and higher income for couples. The results also suggest that working men may have earned more when sex ratios were high. On the other hand, the income married women shared with spouses was partly offset by the loss of female earnings associated with marriage, and by the fact that family income fell when newly married couples formed their own households. Thus, the relationship between first generation sex ratios and second generation standards of living may have been negative, at least in the short run. What were the consequences of changing sex ratios for the third generation, children of the second?

Efforts to assess the causal effect of changing sex ratios on the third generation are complicated by the fact that childbearing is partly a consequence of a process of family formation that was itself shaped by sex ratios. Any association between sex ratios and child outcomes may have been due to changes in the

\footnotetext{
${ }^{16}$ I also explored the effect of excluding individuals in the NEC category. The results for women are similar, though moderately larger in magnitude. The results for men are also broadly similar, though the marriage effect is no longer significant, while the economic results show a significant increase in labor force participation as well as larger wage effects.
} 
characteristics of childbearing couples, or because children were treated differently by their parents. High sex ratios would have reduced average child welfare if, for example, women with lower human capital were more likely to marry and give birth. This is a pure selection effect. On the other hand, high sex ratios may have reduced divorce rates for the same reason they increased marriage rates. This is a causal effect that likely would have benefitted children. The net consequences of both selection and causal effects are of interest, however, even if they cannot be disentangled.

To measure the net effect of changing first-generation sex ratios on the third generation, I reestimated equation (1) weighting by two measures of the number of own children living with each secondgeneration woman. One weighting scheme counts the number of children under age 5 , while the other counts children of all ages. Woman without co-resident children were automatically dropped from the weighted sample, while women living with children contributed as many observations as they have children in the relevant age range. The estimates therefore capture effects on children, as reflected in the living conditions of their parents. In this setup, estimates for women become estimates of effects on mothers, estimates for spouses become estimates of effects on fathers, and estimates for couples capture effects on parents. $^{17}$

Children under 5 from a high-sex-ratio ethnic background were more likely to be living with a married mother and their mothers had lower earnings, though neither of these effects is significantly different from zero. This can be seen in Table VIII, which reports the results from child-weighted estimation of equation (1). The most striking results in the table are the positive and significant associations between sex ratios and father's income score, parent's income score, and per-capita family income. This suggests young children born to parents from a high-sex-ratio environment were economically better off. It is also worth noting that, as in Tables 5 and 6 , the sex ratio matters more than the number of immigrants for economic variables.

\footnotetext{
${ }^{17}$ Statistical inference is based on numbers of mothers and not numbers of children.
} 
The pattern of results changes little when total number of children are used as weights instead of the number of children under age 5. The most important difference is that the negative effects of sex ratios on mothers' labor force participation become larger, with a corresponding reduction in mothers' income and parents income. The effects of sex ratios on fathers' income scores and per-capita family income are almost unchanged. Overall, the estimates in Table VIII support the view that high immigrant sex ratios had small but lasting effects on the economic well-being of children and families, though the results fail to distinguish selection effects from the consequences of changes in parents' behavior. The magnitudes are such that a one standard deviation increase in sex ratios is predicted to have increased parental income by about 1.5 percent.

\section{Summary and Conclusions}

Estimates linking sex ratios and marriage rates date back at least to Groves and Ogburn [1928]. Previous empirical work, however, has paid little attention to problems of reverse causality and has not explored many of the economic and social consequences of changing sex ratios. Imbalanced sex ratios among immigrants provide an opportunity to measure the causal effect of sex ratios on America's second generation. It should be noted, however, that the effects reported here are for changes in group specific sex ratios, while implicitly holding aggregate sex ratios constant. These effects need not reflect the consequences of changes in aggregate sex ratios which cannot be offset by marrying out of the ethnic group when groupspecific sex ratios are highly imbalanced. On the other hand, there is a parallel with the ethnicity strategy if the inter-spouse age gap also adjusts as a partial offset.

Estimates using variation among immigrant groups provide strong evidence for a reduced-form relationship between sex ratios and a range of characteristics related to second generation family structure and economic circumstances. Higher sex ratios are associated with higher marriage rates for both men and women, lower female labor force participation, and higher spouse and couple income. The effects on women are much larger than those for men, though the results for men are consistent with the view that higher sex ratios cause men to marry sooner and to try to become more attractive to potential mates. Results 
for the third generation suggest that children born to parents who married in a high sex ratio environment were better off. A number of specification checks support the notion that the primary factor mediating these links was increased female bargaining power in the marriage market. 


\section{DATA APPENDIX}

A. Ethnicity in the Census

The ethnic groups were coded as follows:

1. British (from England, Scotland, or Wales)

2. Irish, including Northern Ireland

3. Italian (From North or South; mostly Southern)

4. Canadian (From English-speaking or French Canada; mostly French)

5. Mexican (largely refugees from civil war and revolution)

6. Nordic (From Denmark, Finland, Norway, Sweden, or Iceland)

7. German/Austrian (from Germany or Austria, and other ethnic Germans; excluding Jews)

8. Hungarian/Romanian (from Hungary or Romania; excluding Jews)

9. Russian/Polish (from USSR or Russian empire, including Baltic States, from Poland, and other ethnic Poles; excluding Jews)

10. Central and East-European Jews (Jews from the German/Austrian, Hungarian/Romanian, or Russian/Polish groups)

11. Not elsewhere classified (N.E.C.)

This coding scheme was used for both first generation (foreign born) and second generation (foreign and mixed parentage) respondents. In most cases, the ethnicity of the foreign born was assigned by country of birth, while the ethnicity of the second generation was assigned using mother's country of birth, except for those with a foreign father only, in which father's ethnicity was used. Exceptions to these general rules are that in 1910 and 1920, ethnic Germans and ethnic Poles were identified using mother tongue for the foreign born and mother's mother tongue for the second generation. First and second generation Jews in 1910 and 1920 were similarly identified as those listing Yiddish as mother tongue or mother's mother tongue. In 1940, 
ethnic Germans, ethnic Poles, and Jews were identified using mother tongue for both the foreign born and the second generation because the 1940 Census omits information on parents' mother tongue. The coding change in 1940 mostly affects the distinction between Jews and other Russians and Poles.

Although national boundaries changed over the sample period, the ethnicity and nativity variables were recoded in the IPUMS to use a consistent scheme for all years. Every Census from 1870-1970 collected information on nativity, identifying the foreign born, and the foreign-birth status of both parents, but the 1940 and 1950 censuses collected this information for sample-line individuals only. The extracts used here are therefore limited to sample-line individuals for $1940 .{ }^{18}$

\section{B. Ethnicity groups in the arrivals data}

Ferenczi and Willcox [1929] report information for 1899-1924. I added data for 1925-1929 from US Department of Labor [1926, 1929], which are later volumes in the source series used by Ferenczi and Willcox. These sources show numbers of immigrant aliens admitted by sex and "race or people," as well as tables where statistics by race or people are assigned to alternate countries of origin. This information was used to establish the following correspondence. When different, the Ferenczi and Willcox categories appear on the right:
1. British
English, Scottish, Welsh
2. Irish
3. Italian
Italian, North and Italian, South
4. Canadian
French
5. Mexican
6. Nordic
Finnish and Scandanavian
7. German/Austrian
German

\footnotetext{
${ }^{18}$ In 1940 and 1950, one randomly chosen individual in each household was given what later became known as a "Census Long Form" with an extended questionnaire.
} 


$\begin{array}{lll}\text { 8. Hungarian/Rumanian } & \text { Magyar, Rumanian, and Ruthenian } \\ \text { 9. Russian/Polish } & \text { Russian, Polish, Lithuanian } \\ \text { 10. Central/East European Jews } & \text { Hebrews } \\ \text { 11. } & \text { N.E.C } & \end{array}$

Armenian, Bohemian and Moravian, Bulgarian, Serbian and Montenegrin, Croatian and Slovenian, Cuban, Dalmatian, Bosnian, Herzegovinian, Dutch and Flemish, Greek, Portuguese, Slovak, Spanish, Spanish-American, Syrian, Turkish

The arrivals sex ratios are reported in the Appendix Table.

\section{Income Imputation}

The IPUMS provides a variable, OCCSCORE, which contains the median family income in 1950 for each occupation code in each census year. The IPUMS uses a consistent 1950-based occupation code for this purpose. OCCSCORE does not vary by age or sex. I used OCCSCORE to construct an income variable that varies by age and sex, by imputing individual wage and salary income in 1940. This is the only 1940 income variable and the earliest income data available in the Census. The imputation is from a regression of $\log ($ wage and salary earnings in 1940) on $\log ($ OCCSCORE) and a full set of age dummies, separately by sex, for a sample aged 18-59. The sample used to run the regression was limited to those with positive wage and salary earnings. But fitted values were constructed for everyone with an occupation, so an income score is imputed for everyone in the labor force, including those with no wage and salary earnings. Thus, the imputation is essentially an age and sex-specific re-scaling of the underlying OCCSCORE variable. The coefficient on $\log$ (OCCSCORE) for men is 1.02 , while the coefficient for women is .69. In analysis of men in the 1910 Census, Borjas [1994] used a similar imputed wage measure. 
Appendix Table I: Immigrant Arrivals Data

\begin{tabular}{|c|c|c|c|c|c|c|}
\hline \multirow{3}{*}{ Group } & \multicolumn{2}{|c|}{ 1900-1909 } & \multicolumn{2}{|c|}{ 1910-1919 } & \multicolumn{2}{|c|}{ 1920-1929 } \\
\hline & Total & Sex & Total & Sex & Total & Sex \\
\hline & immigrants & ratios & immigrants & ratios & immigrants & ratios \\
\hline British & 430776 & 1.65732 & 598382 & 1.22490 & 798792 & 1.13412 \\
\hline Irish & 368997 & 0.91085 & 257619 & 1.08016 & 348776 & 1.05900 \\
\hline Italian & 1982418 & 3.74366 & 1290899 & 2.60219 & 541961 & 1.50291 \\
\hline Canadian & 92398 & 1.41097 & 172436 & 1.31144 & 247842 & 1.24377 \\
\hline Mexican & 23991 & 1.99438 & 173663 & 1.50318 & 487775 & 2.20109 \\
\hline Nordic & 640961 & 1.66360 & 358893 & 1.69326 & 252966 & 1.62372 \\
\hline German/Austrian & 656363 & 1.47458 & 409725 & 1.31401 & 503159 & 1.14315 \\
\hline Hungarian/Romanian & 491556 & 3.12192 & 359999 & 1.96274 & 57123 & 0.92327 \\
\hline Russian/Polish & 1002442 & 2.40189 & 875191 & 2.10208 & 117269 & 0.92959 \\
\hline Jewish & 952767 & 1.31084 & 561133 & 1.19211 & 342720 & 0.83217 \\
\hline NEC & 1306054 & 3.56021 & 1113618 & 3.15301 & 469384 & 1.46335 \\
\hline
\end{tabular}

The table shows total numbers of alien arrivals and the ratio of men to women among arrivals.

MASSACHUSETTS INSTITUTE OF TECHNOLOGY

NATIONAL BUREAU OF ECONOMIC RESEARCH 


\section{References}

Angrist, Joshua D., 2000, “Consequences of Imbalanced Sex Ratios: Evidence from America’s Second Generation," NBER Working Paper 8042, December.

Becker, Gary S., 1973, “A Theory of Marriage: Part I,” Journal of Political Economy 81, 813-846.

Becker, Gary S., 1981, A Treatise on the Family, Cambridge: Harvard University Press.

Berman, Eli, 1997, "Help Wanted, Job Needed: Estimates of a Matching Function from Employment Service Data," Journal of Labor Economics 15(1, Part 2), S251-S292.

Borjas, George J., Friends or Strangers: The Impact of Immigrants on the U.S. Economy, New York: Basic Books, Inc, 1990.

, "Long-Run Convergence of Ethnic Skill Differentials: The Children and Grandchildren of the Great Migration," Industrial \& Labor Relations Review 47, 553-73, July 1994.

Chiappori, Pierre-Andre, Bernard Fortin, and Guy Lacroix, 2001, "Marriage Market, Divorce Legislation, and Household Labor Supply," Journal of Political Economy, forthcoming.

Chiswick, Barry R., 1977, Sons of Immigrants: Are They at an Earnings Disadvantage?, The American Economic Review, 67, 1, 376-380.

Cox, Oliver C., 1940, Sex Ratio and Marital Status Among Negroes, American Sociological Review 6, 937 947.

Duflo, Esther, 2000, “Grandmothers and Granddaughters: Old-Age Pension and Intra-household Allocation in South Africa," NBER Working Paper 8061, December.

Easterlin, Richard A., 1961, "The American Baby Boom in Historical perspective," The American Economic Review 51, 1-60.

Edin, Kathryn, 2000, “Few Good Men,” The American Prospect 11(4), January 3.

Ferenczi, Imre, and Walter F. Willcox, 1929, International Migrations, Volume I: Statistics, Demographic Monograph No. 7, New York: National Bureau of Economic Research.

Fisher, R. A., 1930, The Genetical Theory of Natural Selection, Oxford: Clarendon Press.

Freiden, Alan, 1974, “The United States Marriage Market," Journal of Political Economy 82, (March/April 1974, Part II), S34-S53.

Goldin, Claudia,,1990, Understanding the Gender Gap, New York: Oxford University Press. , 2000, "Labor Markets in the 20th Century," in S. Engerman and R. Gallman, eds., The Cambridge Economic History of the United States, Volume 3. 
Grossbard-Shechtman, S., 1984, “A Theory of Time in Markets for Labour and Marriage,” Economic Journal 94, 863-882.

, 1985, "Marriage Squeezes and the Marriage Market," in Kingsley Davis and Amyra

Grossbard-Schechtman, eds., Contemporary Marriage: Comparative Perspectives on a

Changing Institution, New York: Russell Sage Publications.

, 1993, On the Economics of Marriage: A Theory of Marriage, Labor, and Divorce, Boulder:

Westview Press.

, and M. Neideffer, 1997, "Women's Hours of Work and Marriage Market Imbalances," in I. Persson and C. Jonung, eds., Economics of the Family and Family Policies, Routledge: London.

Groves, E.R., and W.F. Ogburn, 1928, American Marriage and Family Relationships, New York: Henry Holt and Company.

Guttentag, Marcia and Secord, Paul F., 1983, Too Many Women? The Sex Ratio Question, Beverly Hills: Sage Publications.

Haines, Michael R., 1996, "Long Term Marriage Patterns in the United States from Colonial Times to the Present," National Bureau of Economic Research (Cambridge, MA), NBER Working Paper Series, Historical Paper No. 80.

Heer, David M., and Amyra Grossbard-Shechtman, 1981, "The Impact of the Female Marriage Squeeze and the Contraceptive Revolution on Sex Roles and the Women's Liberation Movement in the United States1960-1975," Journal of Marriage and the Family 43, 49-65.

Hutchinson, E.P., 1956, Immigrants and Their Children, 1850-1950, The Social Science Research Council, New York: John Wiley and Sons.

Jemmot, John B., Ashby, Karen L. and Kathryn Lindenfield, 1989, "Romantic Commitment and the Perceived Availability of Opposite-Sex Persons: On Loving the One You're With," Journal of Applied Social Psychology 19, 1198-1211.

Koerner, Brendan I, 1999, "Where the Boys Aren't," US News and World Report, February 8. Landale, Nancy S. and Tolnay, Stewart E., 1993, Generation, Ethnicity, and Marriage: Historical Patterns in the Northern United States, Demography, 30, 1, 103-126.

Landale, Nancy S. and Tolnay, Stewart E., 1993, Generation, Ethnicity, and Marriage: Historical Patterns in the Northern United States, Demography, 30, 1, 103-126.

Moulton, Brent R., 1986, "Random Group Effects and the Precision of Regression Estimates," Journal of Econometrics 32, 385-397.

Pagnini, Deanna L. and Morgan, S. Phillip, 1990, Intermarriage and Social Distance among U.S. Immigrants at the Turn of the Century, American Journal of Sociology, 96, 2, 405-432. 
Rao, Vijayendra, 1993, The Rising Price of Husbands: A Hedonic Analysis of Dowry Increases in Rural India, Journal of Political Economy, 101, 4, 666-677.

Rodriguez, Cindy, 2000, "From Morocco With Love: In Immigrant Community, Women Have Their Pick of Men," The Boston Sunday Globe, June 11, B1.

Ruggles, Steven, 1987, Prolonged Connections: the Rise of the Extended Family in $19^{\text {th }}$ Century England and America, Madison: University of Wisconsin Press.

Ruggles, Steven, 1991, Comparability of the Public Use Files of the U.S. Census of Population, 1880-1980, Social Science History, 15, 1, 123-158.

Ruggles, Steven, and Matthew Sobek, 1997, Integrated Public Use Microdata Series Version 2.0, Volume 1: User's Guide, Historical Census Projects, University of Minnesota Department of History.

Schoen, Robert, 1983, Measuring the Tightness of a Marriage Squeeze, Demography, 20, 1, 61-78.

Sieff, Daniela F., 1990, Explaining Biased Sex Ratios in Human Populations, Current Anthropology 31, 1, $25-$ 48.

South, Scott J. and Lloyd, Kim M., 1992, Marriage Opportunities and Family Formation: Further Implications of Imbalanced Sex Ratios, Journal of Marriage and the Family, 54, 440-451.

South, Scott J. and Trent, Katherine, 1988, Sex Ratios and Women's Roles: A Cross-National Analysis, American Journal of Sociology, 93, 5, 1096-1115.

Tentler, Leslie Woodcock, “The Working-Class Daughter 1900-1930,” in M. Albin and D. Cavallo, eds., Family Life in America, St. James, NY: Revisionary Press, 1981.

Thomas, Duncan, 1990, "Intra-Household Resource Allocation: An Inferential Approach,” Journal of Human Resources 25, 635-664.

Tyree, Andrea and Donato, Katherine, 1985, The Sex Composition of Legal Immigrants to the United States, Sociology and Social Research, 69, 580-584.

US Bureau of the Census, 1975, Historical Statistics of the United States Colonial Times to 1970, Part 1, Washington: USGPO.

US Department of Labor, 1926, Annual Report of the Commissioner General of Immigration, Report for the fiscal year ended June 30, 1929, Department of Labor Bureau of Immigration, Washington: USGPO.

US Department of Labor, 1929, Annual Report of the Commissioner General of Immigration, Report for the fiscal year ended June 30, 1929, Department of Labor Bureau of Immigration, Washington: USGPO. 
Willcox, Walter F. 1931, “Immigration into the United States,” Chapter II in W.F. Willcox, ed., International Migrations, Volume II: Interpretations, Demographic Monograph No.8, New York: National Bureau of Economic Research.

Wilson, William J., 1987, The Truly Disadvantaged: The Inner City, the Underclass, and Public Policy, Chicago: The University of Chicago Press. 
TABLE I

Descriptive Statistics

\begin{tabular}{|c|c|c|c|c|c|c|}
\hline & \multicolumn{3}{|c|}{ Women, Age 18-33 } & \multicolumn{3}{|c|}{ Men, Age 20-35 } \\
\hline & $\begin{array}{c}\text { Native } \\
\text { (1) }\end{array}$ & $\begin{array}{c}\text { Foreign born } \\
\text { (2) }\end{array}$ & $\begin{array}{c}\text { Second } \\
\text { generation } \\
\text { (3) }\end{array}$ & $\begin{array}{c}\text { Native } \\
\text { (4) }\end{array}$ & $\begin{array}{c}\text { Foreign born } \\
(5)\end{array}$ & $\begin{array}{c}\text { Second } \\
\text { generation } \\
(6)\end{array}$ \\
\hline & \multicolumn{6}{|c|}{ A. 1910 Census } \\
\hline Age & $\begin{array}{l}24.7 \\
(4.5)\end{array}$ & $\begin{array}{l}25.9 \\
(4.4)\end{array}$ & $\begin{array}{l}24.8 \\
(4.5)\end{array}$ & $\begin{array}{l}26.9 \\
(4.6)\end{array}$ & $\begin{array}{l}27.6 \\
(4.4)\end{array}$ & $\begin{array}{l}26.9 \\
(4.7)\end{array}$ \\
\hline Married & 0.592 & 0.665 & 0.475 & 0.521 & 0.490 & 0.402 \\
\hline Ever-married & 0.615 & 0.681 & 0.490 & 0.536 & 0.498 & 0.411 \\
\hline Children in household & $\begin{array}{l}1.0 \\
(1.5)\end{array}$ & $\begin{array}{l}1.2 \\
(1.6)\end{array}$ & $\begin{array}{c}0.7 \\
(1.2)\end{array}$ & $\begin{array}{c}0.8 \\
(1.3)\end{array}$ & $\begin{array}{c}0.7 \\
(1.2)\end{array}$ & $\begin{array}{c}0.6 \\
(1.1)\end{array}$ \\
\hline Mother in household & 0.322 & 0.136 & 0.405 & 0.285 & 0.099 & 0.398 \\
\hline Family size & $\begin{array}{c}4.4 \\
(2.2)\end{array}$ & $\begin{array}{l}4.0 \\
(2.3)\end{array}$ & $\begin{array}{l}4.6 \\
(2.4)\end{array}$ & $\begin{array}{l}3.9 \\
(2.3)\end{array}$ & $\begin{array}{l}3.1 \\
(2.3)\end{array}$ & $\begin{array}{c}4.3 \\
(2.5)\end{array}$ \\
\hline In labor force & 0.256 & 0.348 & 0.379 & 0.961 & 0.987 & 0.966 \\
\hline Imputed wages ( $\$ 1939)$ & $\begin{array}{l}105.9 \\
(212.7)\end{array}$ & $\begin{array}{l}129.9 \\
(216.8)\end{array}$ & $\begin{array}{c}163.2 \\
(247.6)\end{array}$ & $\begin{array}{c}708.2 \\
(464.1)\end{array}$ & $\begin{array}{l}794.6 \\
(362.8)\end{array}$ & $\begin{array}{l}775.7 \\
(459.9)\end{array}$ \\
\hline Imputed family income & $\begin{array}{l}1091.5 \\
(821.5)\end{array}$ & $\begin{array}{l}1117.5 \\
(779.1)\end{array}$ & $\begin{array}{l}1338.1 \\
(1005.5)\end{array}$ & $\begin{array}{l}1157.8 \\
(894.3)\end{array}$ & $\begin{array}{l}1166.4 \\
(825.0)\end{array}$ & $\begin{array}{c}1495.5 \\
(1083.6)\end{array}$ \\
\hline $\begin{array}{l}\text { Sex ratio of foreign born in same } \\
\text { ethnic group }\end{array}$ & & & $\begin{array}{l}1.288 \\
(0.361)\end{array}$ & & & $\begin{array}{l}1.289 \\
(0.359)\end{array}$ \\
\hline \multirow[t]{2}{*}{$\mathrm{N}$} & 26,049 & 7,766 & 11,098 & 25,222 & 11,443 & 10,064 \\
\hline & \multicolumn{6}{|c|}{ B. 1920 Census } \\
\hline Age & $\begin{array}{l}25.0 \\
(4.5)\end{array}$ & $\begin{array}{l}26.6 \\
(4.3)\end{array}$ & $\begin{array}{l}25.1 \\
(4.5)\end{array}$ & $\begin{array}{l}27.1 \\
(4.6)\end{array}$ & $\begin{array}{l}28.9 \\
(4.3)\end{array}$ & $\begin{array}{l}27.0 \\
(4.6)\end{array}$ \\
\hline Married & 0.621 & 0.742 & 0.516 & 0.564 & 0.563 & 0.443 \\
\hline Ever-married & 0.647 & 0.763 & 0.536 & 0.581 & 0.575 & 0.455 \\
\hline Children in household & $\begin{array}{c}1.0 \\
(1.5)\end{array}$ & $\begin{array}{c}1.5 \\
(1.7)\end{array}$ & $\begin{array}{c}0.8 \\
(1.3)\end{array}$ & $\begin{array}{c}0.8 \\
(1.3)\end{array}$ & $\begin{array}{l}1.0 \\
(1.4)\end{array}$ & $\begin{array}{c}0.6 \\
(1.1)\end{array}$ \\
\hline Mother in household & 0.307 & 0.146 & 0.391 & 0.294 & 0.118 & 0.407 \\
\hline Family size & $\begin{array}{c}4.4 \\
(2.2)\end{array}$ & $\begin{array}{c}4.3 \\
(2.2)\end{array}$ & $\begin{array}{l}4.6 \\
(2.3)\end{array}$ & $\begin{array}{l}4.1 \\
(2.3)\end{array}$ & $\begin{array}{l}3.6 \\
(2.3)\end{array}$ & $\begin{array}{c}4.4 \\
(2.4)\end{array}$ \\
\hline In labor force & 0.276 & 0.296 & 0.404 & 0.951 & 0.977 & 0.955 \\
\hline Imputed wages (\$1939) & $\begin{array}{c}130.4 \\
(242.3)\end{array}$ & $\begin{array}{c}133.1 \\
(238.2)\end{array}$ & $\begin{array}{l}194.5 \\
(271.3)\end{array}$ & $\begin{array}{c}742.8 \\
(461.1)\end{array}$ & $\begin{array}{c}861.3 \\
(381.2)\end{array}$ & $\begin{array}{c}799.8 \\
(450.5)\end{array}$ \\
\hline Imputed family income & $\begin{array}{l}1170.6 \\
(885.5)\end{array}$ & $\begin{array}{l}1214.5 \\
(856.7)\end{array}$ & $\begin{array}{c}1468.8 \\
(1028.1)\end{array}$ & $\begin{array}{l}1241.5 \\
(914.2)\end{array}$ & $\begin{array}{l}1251.3 \\
(818.3)\end{array}$ & $\begin{array}{c}1606.3 \\
(1113.5)\end{array}$ \\
\hline $\begin{array}{l}\text { Sex ratio of foreign born in same } \\
\text { ethnic group }\end{array}$ & & & $\begin{array}{l}1.222 \\
(0.309)\end{array}$ & & & $\begin{array}{c}1.224 \\
(0.308)\end{array}$ \\
\hline $\mathrm{N}$ & 76,082 & 18,282 & 31,538 & 72,044 & 23,920 & 28,547 \\
\hline
\end{tabular}


TABLE I (cont.)

Descriptive Statistics

\begin{tabular}{|c|c|c|c|c|c|c|}
\hline & \multicolumn{3}{|c|}{ Women, Age 18-33 } & \multicolumn{3}{|c|}{ Men, Age 20-35 } \\
\hline & $\begin{array}{c}\text { Native } \\
\text { (1) }\end{array}$ & $\begin{array}{c}\text { Foreign-born } \\
(2) \\
\end{array}$ & $\begin{array}{c}\text { Second } \\
\text { generation } \\
(3) \\
\end{array}$ & $\begin{array}{c}\text { Native } \\
\text { (4) }\end{array}$ & $\begin{array}{c}\text { Foreign-born } \\
(5) \\
\end{array}$ & $\begin{array}{c}\text { Second } \\
\text { generation } \\
(6) \\
\end{array}$ \\
\hline & \multicolumn{6}{|c|}{ C. 1940 Census } \\
\hline Age & $\begin{array}{l}25.1 \\
(4.6)\end{array}$ & $\begin{array}{l}27.4 \\
(4.4)\end{array}$ & $\begin{array}{l}25.1 \\
(4.5)\end{array}$ & $\begin{array}{l}27.1 \\
(4.6)\end{array}$ & $\begin{array}{l}29.5 \\
(4.4)\end{array}$ & $\begin{array}{l}27.0 \\
(4.5)\end{array}$ \\
\hline Married & 0.635 & 0.679 & 0.504 & 0.594 & 0.618 & 0.455 \\
\hline Ever-married & 0.662 & 0.706 & 0.522 & 0.608 & 0.630 & 0.464 \\
\hline Children in household & $\begin{array}{c}0.9 \\
(1.3)\end{array}$ & $\begin{array}{l}1.01 \\
(1.4)\end{array}$ & $\begin{array}{c}0.6 \\
(1.1)\end{array}$ & $\begin{array}{c}0.7 \\
(1.2)\end{array}$ & $\begin{array}{c}0.8 \\
(1.2)\end{array}$ & $\begin{array}{c}0.5 \\
(1.0)\end{array}$ \\
\hline Mother in household & 0.296 & 0.230 & 0.429 & 0.317 & 0.248 & 0.444 \\
\hline Family size & $\begin{array}{l}4.0 \\
(2.1)\end{array}$ & $\begin{array}{c}3.9 \\
(2.0)\end{array}$ & $\begin{array}{c}4.3 \\
(2.2)\end{array}$ & $\begin{array}{c}3.9 \\
(2.1)\end{array}$ & $\begin{array}{c}3.8 \\
(2.0)\end{array}$ & $\begin{array}{l}4.3 \\
(2.2)\end{array}$ \\
\hline In labor force & 0.328 & 0.385 & 0.464 & 0.931 & 0.945 & 0.931 \\
\hline Imputed wages (\$1939) & $\begin{array}{c}169.7 \\
(270.6)\end{array}$ & $\begin{array}{c}205.1 \\
(289.9)\end{array}$ & $\begin{array}{c}241.3 \\
(290.3)\end{array}$ & 744.6 & $\begin{array}{c}893.6 \\
(461.0)\end{array}$ & $\begin{array}{c}784.3 \\
(449.5)\end{array}$ \\
\hline Actual wages & $\begin{array}{c}199.5 \\
(389.3)\end{array}$ & $\begin{array}{c}240.0 \\
(411.3)\end{array}$ & $\begin{array}{c}289.7 \\
(443.6)\end{array}$ & $\begin{array}{c}748.4 \\
(759.4)\end{array}$ & $\begin{array}{c}946.0 \\
(811.0)\end{array}$ & $\begin{array}{c}819.4 \\
(767.6)\end{array}$ \\
\hline Imputed family income & $\begin{array}{l}1173.3 \\
(781.6)\end{array}$ & $\begin{array}{l}1284.8 \\
(798.5)\end{array}$ & $\begin{array}{l}1497.6 \\
(944.3)\end{array}$ & $\begin{array}{l}1271.4 \\
(840.7)\end{array}$ & $\begin{array}{l}1447.6 \\
(894.5)\end{array}$ & $\begin{array}{c}1642.1 \\
(1040.2)\end{array}$ \\
\hline Actual family wages & $\begin{array}{c}1246.4 \\
(1228.7)\end{array}$ & $\begin{array}{c}1495.3 \\
(1286.2)\end{array}$ & $\begin{array}{c}1598.3 \\
(1296.6)\end{array}$ & $\begin{array}{c}1267.4 \\
(1257.5)\end{array}$ & $\begin{array}{c}1517.9 \\
(1287.1)\end{array}$ & $\begin{array}{c}1678.4 \\
(1371.7)\end{array}$ \\
\hline $\begin{array}{l}\text { Sex ratio of foreign born in same } \\
\text { ethnic group }\end{array}$ & & & $\begin{array}{l}1.146 \\
(0.253)\end{array}$ & & & $\begin{array}{l}1.155 \\
(0.259)\end{array}$ \\
\hline $\mathrm{N}$ & 33,091 & 2,178 & 10,442 & 31,633 & 2,479 & 10,373 \\
\hline
\end{tabular}

The table shows means and standard deviations by nativity and census year. The standard deviations are in parentheses. Statistics are weighted by the IPUMS Sample-line weight. The sample excludes the institutionalized. 
TABLE II

Ethnicity and Sex Distribution Among Foreign Stock

\begin{tabular}{|c|c|c|c|c|c|c|}
\hline \multirow[b]{2}{*}{ Ethnicity } & \multicolumn{3}{|c|}{ Distribution } & \multicolumn{3}{|c|}{ Sex ratios } \\
\hline & $\begin{array}{c}1910 \\
(1)\end{array}$ & $\begin{array}{c}1920 \\
(2)\end{array}$ & $\begin{array}{c}1940 \\
\text { (3) }\end{array}$ & $\begin{array}{c}1910 \\
(4)\end{array}$ & $\begin{array}{c}1920 \\
(5)\end{array}$ & $\begin{array}{c}1940 \\
\text { (6) }\end{array}$ \\
\hline & \multicolumn{6}{|c|}{ A. Foreign-Born } \\
\hline British & 7.0 & 5.8 & 8.7 & 1.17 & 1.02 & 0.94 \\
\hline Irish & 7.2 & 4.4 & 6.0 & 0.72 & 0.60 & 0.65 \\
\hline Italian & 14.2 & 15.6 & 12.4 & 2.21 & 1.46 & 1.04 \\
\hline Canadian & 7.8 & 6.6 & 15.9 & 0.96 & 0.84 & 0.78 \\
\hline Mexican & 1.4 & 4.4 & 6.4 & 1.67 & 1.47 & 0.98 \\
\hline Nordic & 9.6 & 7.1 & 4.3 & 1.39 & 1.29 & 1.23 \\
\hline German / Austrian & 18.9 & 11.7 & 14.9 & 1.24 & 1.10 & 1.04 \\
\hline Hungarian / Romanian & 4.7 & 3.5 & 2.3 & 1.81 & 1.03 & 0.56 \\
\hline Russian / Polish Non-Jews & 13.4 & 19.1 & 8.4 & 1.71 & 1.18 & 0.78 \\
\hline Central / Eastern European Jews & 9.6 & 9.4 & 7.0 & 1.10 & 1.00 & 0.75 \\
\hline \multirow[t]{2}{*}{ N.E.C. } & 6.3 & 12.5 & 13.7 & 2.59 & 1.78 & 1.11 \\
\hline & \multicolumn{6}{|c|}{ B. Second Generation } \\
\hline British & 12.7 & 11.0 & 5.9 & 0.95 & 0.93 & 0.96 \\
\hline Irish & 20.0 & 14.5 & 6.0 & 0.89 & 0.90 & 0.99 \\
\hline Italian & 1.5 & 3.6 & 18.1 & 1.19 & 1.04 & 1.03 \\
\hline Canadian & 9.3 & 9.8 & 6.6 & 0.93 & 0.89 & 0.95 \\
\hline Mexican & 0.6 & 0.7 & 2.2 & 1.09 & 1.00 & 1.26 \\
\hline Nordic & 9.2 & 12.2 & 8.8 & 1.02 & 0.99 & 1.03 \\
\hline German / Austrian & 39.9 & 33.0 & 16.5 & 0.99 & 0.96 & 1.01 \\
\hline Hungarian / Romanian & 0.2 & 0.5 & 2.6 & 0.87 & 1.04 & 1.08 \\
\hline Russian / Polish Non-Jews & 2.2 & 5.5 & 19.4 & 1.11 & 0.96 & 0.95 \\
\hline Central / Eastern European Jews & 1.3 & 2.7 & 4.9 & 1.02 & 0.98 & 0.95 \\
\hline N.E.C. & 3.2 & 6.5 & 9.1 & 0.97 & 0.97 & 0.98 \\
\hline
\end{tabular}

Columns 1-3 show the ethnicity distribution of foreign-born and second generation men and women aged 18-35. Columns 4-6 show sex ratios by ethnicity and generation. Statistics are weighted by the IPUMS sample-line weight. 
TABLE III

Endogamy in the First and Second Generation (1910-20 Only)

\begin{tabular}{|c|c|c|c|c|c|c|}
\hline \multirow[b]{3}{*}{ Nativity } & \multicolumn{3}{|c|}{ Women 18-33 } & \multicolumn{3}{|c|}{ Men 20-35 } \\
\hline & Married native & $\begin{array}{c}\text { Endogamous } \\
\text { marriage }\end{array}$ & $\begin{array}{l}\text { Married other } \\
\text { foreign stock }\end{array}$ & Married native & $\begin{array}{c}\text { Endogamous } \\
\text { marriage }\end{array}$ & $\begin{array}{l}\text { Married other } \\
\text { foreign stock }\end{array}$ \\
\hline & (1) & (2) & (3) & (4) & (5) & (6) \\
\hline Native & 84.7 & - & 15.3 & 85.1 & - & 14.9 \\
\hline \multicolumn{7}{|l|}{ 2nd Generation } \\
\hline British & 53.0 & 19.8 & 27.2 & 54.1 & 18.5 & 27.4 \\
\hline Irish & 38.9 & 30.9 & 30.2 & 41.3 & 30.6 & 28.1 \\
\hline Italian & 5.8 & 86.1 & 8.1 & 21.5 & 49.3 & 29.2 \\
\hline Canadian & 44.1 & 30.6 & 25.3 & 43.3 & 31.1 & 25.6 \\
\hline Mexican & 12.4 & 80.9 & 6.7 & 17.2 & 77.9 & 4.9 \\
\hline Nordic & 33.2 & 45.0 & 21.8 & 34.5 & 43.4 & 22.1 \\
\hline German / Austrian & 34.9 & 48.5 & 16.6 & 38.9 & 45.3 & 15.8 \\
\hline Hungarian / Romanian & 10.5 & 48.4 & 41.1 & 20.0 & 30.6 & 49.4 \\
\hline Russian / Polish Non-Jews & 6.5 & 77.4 & 16.1 & 11.0 & 70.9 & 18.1 \\
\hline Central / Eastern European Jews & 1.2 & 86.7 & 12.1 & 5.3 & 77.3 & 17.4 \\
\hline $2^{\text {nd }}$ Generation, NEC & 30.7 & 40.1 & 29.2 & 37.2 & 35.2 & 27.6 \\
\hline \multicolumn{7}{|l|}{ Foreign-born } \\
\hline British & 26.4 & 49.1 & 24.5 & 26.1 & 48.2 & 25.7 \\
\hline Irish & 15.0 & 67.3 & 17.7 & 8.8 & 78.4 & 12.8 \\
\hline Italian & 0.3 & 98.6 & 1.1 & 3.1 & 93.0 & 3.9 \\
\hline Canadian & 30.1 & 50.0 & 19.9 & 25.3 & 54.4 & 20.3 \\
\hline Mexican & 4.3 & 92.0 & 3.7 & 6.8 & 92.0 & 1.2 \\
\hline Nordic & 7.1 & 82.7 & 10.2 & 10.3 & 80.2 & 9.5 \\
\hline German / Austrian & 9.4 & 79.9 & 10.7 & 10.3 & 80.0 & 9.7 \\
\hline Hungarian / Romanian & 0.3 & 89.1 & 10.6 & 0.7 & 88.5 & 10.8 \\
\hline Russian / Polish Non-Jews & 0.6 & 94.7 & 4.7 & 1.3 & 93.6 & 5.1 \\
\hline Central / Eastern European Jews & 0.3 & 97.3 & 2.4 & 0.4 & 95.9 & 3.7 \\
\hline $2^{\text {nd }}$ Generation, NEC & 6.5 & 82.5 & 11.0 & 9.9 & 75.0 & 15.1 \\
\hline
\end{tabular}

The table shows the distribution of spouses' ethnicity for married men aged 20-35 and married women aged 18-33 in the 1910 and 1920 censuses with spouse present. Endogamous marriages are those to men or women of the same ethnic background, either first or second generation. Marriages to other foreign stock also include marriages to first and second generation spouses. 
TABLE IV

First Stage Estimates

\begin{tabular}{|c|c|c|c|c|c|c|c|c|c|}
\hline \multirow[b]{3}{*}{$\begin{array}{l}\text { Endogenous } \\
\text { variable }\end{array}$} & \multirow[b]{3}{*}{$\begin{array}{c}\text { Excluded } \\
\text { instruments }\end{array}$} & \multicolumn{4}{|c|}{ Foreign-born sex ratio endogenous } & \multicolumn{4}{|c|}{ Foreign stock sex ratio endogenous } \\
\hline & & \multicolumn{2}{|c|}{ Women } & \multicolumn{2}{|c|}{ Men } & \multicolumn{2}{|c|}{ Women } & \multicolumn{2}{|c|}{ Men } \\
\hline & & $\begin{array}{l}\text { Dependent } \\
\text { mean } \\
\text { (1) }\end{array}$ & $\begin{array}{c}\text { Coefficient } \\
\text { (2) }\end{array}$ & $\begin{array}{l}\text { Dependent } \\
\text { mean } \\
\text { (3) }\end{array}$ & $\begin{array}{c}\text { Coefficient } \\
\text { (4) }\end{array}$ & $\begin{array}{l}\text { Dependent } \\
\text { mean } \\
(5)\end{array}$ & $\begin{array}{c}\text { Coefficient } \\
\text { (6) }\end{array}$ & $\begin{array}{l}\text { Dependent } \\
\text { mean } \\
\text { (7) }\end{array}$ & $\begin{array}{c}\text { Coefficient } \\
\text { (8) }\end{array}$ \\
\hline & & A. Young & er Cohort & Women 18- & 33, Men 2 & 35) & & & \\
\hline \multirow[t]{2}{*}{ Sex ratio } & $\begin{array}{l}\text { Arrivals } \\
\text { ratio }\end{array}$ & 1.21 & $\begin{array}{c}0.531 \\
(0.026)\end{array}$ & 1.22 & $\begin{array}{c}0.534 \\
(0.027)\end{array}$ & 1.02 & $\begin{array}{c}0.357 \\
(0.018)\end{array}$ & 1.02 & $\begin{array}{c}0.355 \\
(0.019)\end{array}$ \\
\hline & $\begin{array}{c}\log (\text { Immigration } \\
\text { Count })\end{array}$ & & $\begin{array}{l}-0.082 \\
(0.022)\end{array}$ & & $\begin{array}{l}-0.084 \\
(0.022)\end{array}$ & & $\begin{array}{l}-0.004 \\
(0.015)\end{array}$ & & $\begin{array}{c}-0.002 \\
(0.015)\end{array}$ \\
\hline \multirow[t]{2}{*}{$\begin{array}{l}\log (\text { Number of } \\
\text { foreign born)* }\end{array}$} & $\begin{array}{l}\text { Arrivals } \\
\text { ratio }\end{array}$ & 12.6 & $\begin{array}{l}-0.390 \\
(0.056)\end{array}$ & 12.5 & $\begin{array}{c}-0.402 \\
(0.056)\end{array}$ & 12.6 & $\begin{array}{l}-0.390 \\
(0.056)\end{array}$ & 12.5 & $\begin{array}{l}-0.402 \\
(0.056)\end{array}$ \\
\hline & $\begin{array}{l}\log (\text { Immigration } \\
\text { count })\end{array}$ & & $\begin{array}{c}0.617 \\
(0.047)\end{array}$ & & $\begin{array}{c}0.623 \\
(0.046)\end{array}$ & & $\begin{array}{c}0.617 \\
(0.047)\end{array}$ & & $\begin{array}{c}0.623 \\
(0.046)\end{array}$ \\
\hline $\mathrm{N}$ & & \multicolumn{2}{|c|}{53,078} & \multicolumn{2}{|c|}{48,984} & \multicolumn{2}{|c|}{53,078} & \multicolumn{2}{|c|}{48,984} \\
\hline \multicolumn{10}{|c|}{ B. Older Cohort (Women 34-48, Men 36-50) } \\
\hline \multirow[t]{2}{*}{ Sex ratio } & $\begin{array}{l}\text { Arrivals } \\
\text { ratio }\end{array}$ & 1.15 & $\begin{array}{c}0.236 \\
(0.035)\end{array}$ & 1.16 & $\begin{array}{c}0.234 \\
(0.035)\end{array}$ & 1.04 & $\begin{array}{c}0.146 \\
(0.019)\end{array}$ & 1.04 & $\begin{array}{c}0.144 \\
(0.019)\end{array}$ \\
\hline & $\begin{array}{c}\log (\text { Immigration } \\
\text { count })\end{array}$ & & $\begin{array}{l}-0.053 \\
(0.030)\end{array}$ & & $\begin{array}{c}-0.058 \\
(0.030)\end{array}$ & & $\begin{array}{c}0.044 \\
(0.016)\end{array}$ & & $\begin{array}{c}0.034 \\
(0.016)\end{array}$ \\
\hline \multirow[t]{2}{*}{$\begin{array}{l}\log (\text { Number of } \\
\text { foreign born)* }\end{array}$} & $\begin{array}{l}\text { Arrivals } \\
\text { ratio }\end{array}$ & 13.0 & $\begin{array}{l}-0.596 \\
(0.046)\end{array}$ & 13.0 & $\begin{array}{l}-0.614 \\
(0.046)\end{array}$ & 13.0 & $\begin{array}{l}-0.596 \\
(0.046)\end{array}$ & 13.0 & $\begin{array}{l}-0.614 \\
(0.046)\end{array}$ \\
\hline & $\begin{array}{c}\log (\text { Immigration } \\
\text { count })\end{array}$ & & $\begin{array}{c}0.118 \\
(0.039)\end{array}$ & & $\begin{array}{c}0.155 \\
(0.039)\end{array}$ & & $\begin{array}{c}0.118 \\
(0.039)\end{array}$ & & $\begin{array}{c}0.155 \\
(0.039)\end{array}$ \\
\hline $\mathrm{N}$ & & \multicolumn{2}{|c|}{33,441} & \multicolumn{2}{|c|}{31,626} & \multicolumn{2}{|c|}{33,441} & \multicolumn{2}{|c|}{31,626} \\
\hline
\end{tabular}

The table reports coefficients from regressions of the indicated endogenous variables on arrivals ratios and log (number of arrivals) by year and ethnicity. There are 33 ethnicity-year cells, with microdata sample sizes as indicated in the table. Standard errors adjusted for ethnicity-year clustering are reported in parentheses. The endogenous (i.e., left-hand side) variables are the sex ratio and number of immigrants estimated using census data. The excluded instruments are the sex ratio and number of arrivals reported by US immigration authorities. The sex ratio estimates in columns 1-4 are for foreign-born sex ratios, while the results in columns 5-8 are for foreign-stock sex ratios. The $\ln$ (number of foreign born) results are the same in columns 1-4 and 5-8. 
TABLE V

OLS and IV Estimates for Women Aged 18-33

\begin{tabular}{|c|c|c|c|c|c|c|}
\hline \multirow{4}{*}{ Dependent variable } & \multirow{4}{*}{$\begin{array}{c}\text { Mean } \\
(1)\end{array}$} & \multirow{4}{*}{ Regressor } & \multicolumn{4}{|c|}{ Model } \\
\hline & & & \multicolumn{2}{|c|}{$\begin{array}{l}\text { Foreign born ratio } \\
\text { endogenous }\end{array}$} & \multicolumn{2}{|c|}{$\begin{array}{c}\text { Foreign stock ratio } \\
\text { endogenous }\end{array}$} \\
\hline & & & OLS & 2SLS & OLS & $2 \mathrm{SLS}$ \\
\hline & & & (2) & (3) & (4) & (5) \\
\hline & & A. Family & tructure & & & \\
\hline \multirow[t]{2}{*}{ Ever married } & 0.517 & Sex ratio & $\begin{array}{c}0.132 \\
(0.015)\end{array}$ & $\begin{array}{c}0.150 \\
(0.018)\end{array}$ & $\begin{array}{c}0.177 \\
(0.019)\end{array}$ & $\begin{array}{c}0.203 \\
(0.024)\end{array}$ \\
\hline & & $\begin{array}{l}\text { Ln (\# Foreign } \\
\text { born) }\end{array}$ & $\begin{array}{c}0.023 \\
(0.011)\end{array}$ & $\begin{array}{l}0.005 \\
(0.013)\end{array}$ & $\begin{array}{c}0.005 \\
(0.010)\end{array}$ & $\begin{array}{l}-0.014 \\
(0.013)\end{array}$ \\
\hline \multirow[t]{2}{*}{ Currently married } & 0.500 & Sex ratio & $\begin{array}{c}0.124 \\
(0.015)\end{array}$ & $\begin{array}{c}0.143 \\
(0.018)\end{array}$ & $\begin{array}{c}0.169 \\
(0.019)\end{array}$ & $\begin{array}{c}0.194 \\
(0.024)\end{array}$ \\
\hline & & $\begin{array}{l}\text { Ln (\# Foreign } \\
\text { born) }\end{array}$ & $\begin{array}{c}0.020 \\
(0.011)\end{array}$ & $\begin{array}{c}0.003 \\
(0.013)\end{array}$ & $\begin{array}{c}0.004 \\
(0.010)\end{array}$ & $\begin{array}{l}-0.015 \\
(0.013)\end{array}$ \\
\hline \multirow[t]{2}{*}{ Own children in household } & 0.358 & Sex ratio & $\begin{array}{c}0.121 \\
(0.015)\end{array}$ & $\begin{array}{c}0.129 \\
(0.017)\end{array}$ & $\begin{array}{c}0.159 \\
(0.019)\end{array}$ & $\begin{array}{c}0.174 \\
(0.023)\end{array}$ \\
\hline & & $\begin{array}{l}\text { Ln (\# Foreign } \\
\text { born) }\end{array}$ & $\begin{array}{c}0.045 \\
(0.010)\end{array}$ & $\begin{array}{c}0.040 \\
(0.012)\end{array}$ & $\begin{array}{c}0.029 \\
(0.010)\end{array}$ & $\begin{array}{c}0.024 \\
(0.012)\end{array}$ \\
\hline \multirow[t]{2}{*}{ Mother in household } & 0.409 & Sex ratio & $\begin{array}{l}-0.099 \\
(0.020)\end{array}$ & $\begin{array}{l}-0.093 \\
(0.023)\end{array}$ & $\begin{array}{l}-0.123 \\
(0.025)\end{array}$ & $\begin{array}{l}-0.125 \\
(0.031)\end{array}$ \\
\hline & & $\begin{array}{l}\text { Ln (\# Foreign } \\
\text { born) }\end{array}$ & $\begin{array}{l}-0.036 \\
(0.015)\end{array}$ & $\begin{array}{l}-0.026 \\
(0.017)\end{array}$ & $\begin{array}{l}-0.023 \\
(0.014)\end{array}$ & $\begin{array}{l}-0.015 \\
(0.017)\end{array}$ \\
\hline \multirow[t]{2}{*}{ Family size } & 4.485 & Sex ratio & $\begin{array}{l}-0.175 \\
(0.142)\end{array}$ & $\begin{array}{l}-0.178 \\
(0.165)\end{array}$ & $\begin{array}{l}-0.170 \\
(0.175)\end{array}$ & $\begin{array}{l}-0.241 \\
(0.224)\end{array}$ \\
\hline & & $\begin{array}{l}\text { Ln (\# Foreign } \\
\text { born) }\end{array}$ & $\begin{array}{c}0.244 \\
(0.108)\end{array}$ & $\begin{array}{c}0.343 \\
(0.128)\end{array}$ & $\begin{array}{c}0.270 \\
(0.103)\end{array}$ & $\begin{array}{c}0.365 \\
(0.129)\end{array}$ \\
\hline \multirow[t]{2}{*}{ \# Aged 14-69 in family } & 3.379 & Sex ratio & $\begin{array}{l}-0.521 \\
(0.096)\end{array}$ & $\begin{array}{l}-0.572 \\
(0.111)\end{array}$ & $\begin{array}{l}-0.681 \\
(0.120)\end{array}$ & $\begin{array}{l}-0.773 \\
(0.151)\end{array}$ \\
\hline & & $\begin{array}{l}\text { Ln (\# Foreign } \\
\text { born) }\end{array}$ & $\begin{array}{l}-0.045 \\
(0.072)\end{array}$ & $\begin{array}{c}0.013 \\
(0.085)\end{array}$ & $\begin{array}{c}0.023 \\
(0.069)\end{array}$ & $\begin{array}{c}0.085 \\
(0.087)\end{array}$ \\
\hline \multirow[t]{2}{*}{$\begin{array}{l}\text { Respondent is head of } \\
\text { household }\end{array}$} & 0.018 & Sex ratio & $\begin{array}{c}0.009 \\
(0.004)\end{array}$ & $\begin{array}{c}0.009 \\
(0.005)\end{array}$ & $\begin{array}{c}0.011 \\
(0.005)\end{array}$ & $\begin{array}{c}0.013 \\
(0.007)\end{array}$ \\
\hline & & $\begin{array}{l}\text { Ln (\# Foreign } \\
\text { born) }\end{array}$ & $\begin{array}{c}0.008 \\
(0.003)\end{array}$ & $\begin{array}{c}0.009 \\
(0.003)\end{array}$ & $\begin{array}{c}0.007 \\
(0.003)\end{array}$ & $\begin{array}{c}0.008 \\
(0.003)\end{array}$ \\
\hline
\end{tabular}


TABLE V (cont.)

OLS and IV Estimates for Women Aged 18-33

\begin{tabular}{|c|c|c|c|c|c|c|}
\hline \multirow{4}{*}{ Dependent Variable } & \multirow{4}{*}{$\begin{array}{c}\text { Mean } \\
(1)\end{array}$} & \multirow{4}{*}{ Regressor } & \multicolumn{4}{|c|}{ Model } \\
\hline & & & \multicolumn{2}{|c|}{$\begin{array}{l}\text { Foreign born ratio } \\
\text { endogenous }\end{array}$} & \multicolumn{2}{|c|}{$\begin{array}{c}\text { Foreign stock ratio } \\
\text { endogenous }\end{array}$} \\
\hline & & & OLS & 2SLS & OLS & 2SLS \\
\hline & & & (2) & (3) & (4) & (5) \\
\hline & & B. Economic & Outcomes & & & \\
\hline \multirow[t]{2}{*}{ In the labor force } & 0.420 & Sex ratio & $\begin{array}{l}-0.098 \\
(0.015)\end{array}$ & $\begin{array}{l}-0.099 \\
(0.017)\end{array}$ & $\begin{array}{l}-0.122 \\
(0.019)\end{array}$ & $\begin{array}{l}-0.134 \\
(0.023)\end{array}$ \\
\hline & & $\begin{array}{l}\text { Ln (\# Foreign } \\
\text { born) }\end{array}$ & $\begin{array}{l}-0.029 \\
(0.010)\end{array}$ & $\begin{array}{l}-0.012 \\
(0.012)\end{array}$ & $\begin{array}{l}-0.016 \\
(0.010)\end{array}$ & $\begin{array}{c}0.001 \\
(0.012)\end{array}$ \\
\hline \multirow[t]{2}{*}{ Occupational income score } & 203.3 & Sex ratio & $\begin{array}{l}-57.21 \\
(8.03)\end{array}$ & $\begin{array}{l}-54.38 \\
(8.91)\end{array}$ & $\begin{array}{l}-72.14 \\
(10.52)\end{array}$ & $\begin{array}{l}-73.51 \\
(12.32)\end{array}$ \\
\hline & & $\begin{array}{l}\text { Ln (\# Foreign } \\
\text { born) }\end{array}$ & $\begin{array}{l}-25.69 \\
(5.19)\end{array}$ & $\begin{array}{l}-20.08 \\
(6.16)\end{array}$ & $\begin{array}{l}-18.24 \\
(5.17)\end{array}$ & $\begin{array}{l}-13.28 \\
(6.39)\end{array}$ \\
\hline \multirow[t]{2}{*}{ Log occupational wage } & 6.099 & Sex ratio & $\begin{array}{l}-0.021 \\
(0.015)\end{array}$ & $\begin{array}{l}-0.012 \\
(0.017)\end{array}$ & $\begin{array}{l}-0.042 \\
(0.020)\end{array}$ & $\begin{array}{l}-0.016 \\
(0.023)\end{array}$ \\
\hline & & $\begin{array}{l}\text { Ln (\# Foreign } \\
\text { born) }\end{array}$ & $\begin{array}{l}-0.031 \\
(0.010)\end{array}$ & $\begin{array}{l}-0.039 \\
(0.012)\end{array}$ & $\begin{array}{l}-0.028 \\
(0.010)\end{array}$ & $\begin{array}{l}-0.037 \\
(0.012)\end{array}$ \\
\hline \multirow[t]{2}{*}{ Spouse's income score } & 473.0 & Sex ratio & $\begin{array}{l}112.4 \\
(17.1)\end{array}$ & $\begin{array}{l}125.6 \\
(19.3)\end{array}$ & $\begin{array}{l}148.5 \\
(21.7)\end{array}$ & $\begin{array}{l}169.8 \\
(25.9)\end{array}$ \\
\hline & & $\begin{array}{l}\text { Ln (\# Foreign } \\
\text { born) }\end{array}$ & $\begin{array}{c}19.0 \\
(11.4)\end{array}$ & $\begin{array}{c}6.6 \\
(13.8)\end{array}$ & $\begin{array}{c}4.3 \\
(11.0)\end{array}$ & $\begin{array}{c}-9.1 \\
(13.8)\end{array}$ \\
\hline \multirow[t]{2}{*}{$\begin{array}{l}\text { Combined husband and } \\
\text { wife income score }\end{array}$} & 676.4 & Sex ratio & $\begin{array}{c}55.54 \\
(15.91)\end{array}$ & $\begin{array}{l}71.66 \\
(18.10)\end{array}$ & $\begin{array}{c}76.74 \\
(20.11)\end{array}$ & $\begin{array}{c}96.87 \\
(24.21)\end{array}$ \\
\hline & & $\begin{array}{l}\text { Ln (\# Foreign } \\
\text { born) }\end{array}$ & $\begin{array}{c}-6.66 \\
(10.93)\end{array}$ & $\begin{array}{l}-13.50 \\
(13.13)\end{array}$ & $\begin{array}{l}-13.93 \\
(10.44)\end{array}$ & $\begin{array}{l}-22.46 \\
(13.05)\end{array}$ \\
\hline \multirow[t]{2}{*}{ Family income score } & 1456.4 & Sex ratio & $\begin{array}{l}-206.2 \\
(42.4)\end{array}$ & $\begin{array}{l}-218.5 \\
(48.2)\end{array}$ & $\begin{array}{l}-270.6 \\
(53.4)\end{array}$ & $\begin{array}{l}-295.3 \\
(65.8)\end{array}$ \\
\hline & & $\begin{array}{l}\text { Ln (\# Foreign } \\
\text { born) }\end{array}$ & $\begin{array}{l}-51.1 \\
(30.8)\end{array}$ & $\begin{array}{l}-22.9 \\
(36.2)\end{array}$ & $\begin{array}{l}-24.2 \\
(29.6)\end{array}$ & $\begin{array}{c}4.4 \\
(36.9)\end{array}$ \\
\hline \multirow[t]{2}{*}{$\begin{array}{l}\text { Family income score per } \\
\text { member aged } 14-69\end{array}$} & 451.2 & Sex ratio & $\begin{array}{c}5.63 \\
(7.56)\end{array}$ & $\begin{array}{c}7.07 \\
(8.55)\end{array}$ & $\begin{array}{c}8.06 \\
(9.62)\end{array}$ & $\begin{array}{c}9.55 \\
(11.54)\end{array}$ \\
\hline & & $\begin{array}{l}\text { Ln (\# Foreign } \\
\text { born) }\end{array}$ & $\begin{array}{l}-6.78 \\
(5.20)\end{array}$ & $\begin{array}{l}-6.10 \\
(6.19)\end{array}$ & $\begin{array}{l}-7.52 \\
(5.01)\end{array}$ & $\begin{array}{l}-6.98 \\
(6.23)\end{array}$ \\
\hline
\end{tabular}

The table reports OLS and 2SLS estimates of equation (1) in the text. Other regressors in the model include year, ethnicity, and age effects and dummies for nativity status. Standard errors adjusted for ethnicity-year clustering are reported in parentheses. The endogenous variables in columns (3) and (5) are the sex ratio and number of immigrants estimated from the census. The excluded instruments are the sex ratio and number of arrivals reported by US immigration authorities. The sample includes 53,078 observations from the 1910, 1920, and 1940 IPUMS files, except for the log wage results, which use a sample of 21,374 , and some of the income variables, for which sample sizes are slightly below the maximum possible. 
TABLE VI

OLS and IV Estimates for Men Aged 20-35

\begin{tabular}{|c|c|c|c|c|c|c|}
\hline \multirow{4}{*}{ Dependent variable } & \multirow{4}{*}{$\begin{array}{c}\text { Mean } \\
(1)\end{array}$} & \multirow{4}{*}{ Regressor } & \multicolumn{4}{|c|}{ Model } \\
\hline & & & \multicolumn{2}{|c|}{$\begin{array}{c}\text { Foreign born ratio } \\
\text { endogenous }\end{array}$} & \multicolumn{2}{|c|}{$\begin{array}{c}\text { Foreign stock ratio } \\
\text { endogenous }\end{array}$} \\
\hline & & & OLS & 2SLS & OLS & 2SLS \\
\hline & & & (2) & (3) & (4) & (5) \\
\hline \multicolumn{7}{|c|}{ A. Family Structure } \\
\hline \multirow[t]{2}{*}{ Ever married } & 0.447 & Sex ratio & $\begin{array}{c}0.025 \\
(0.015)\end{array}$ & $\begin{array}{c}0.036 \\
(0.017)\end{array}$ & $\begin{array}{c}0.007 \\
(0.019)\end{array}$ & $\begin{array}{c}0.048 \\
(0.024)\end{array}$ \\
\hline & & $\begin{array}{l}\text { Ln (\# Foreign } \\
\text { born) }\end{array}$ & $\begin{array}{c}0.002 \\
(0.010)\end{array}$ & $\begin{array}{c}0.000 \\
(0.012)\end{array}$ & $\begin{array}{l}-0.002 \\
(0.010)\end{array}$ & $\begin{array}{l}-0.005 \\
(0.013)\end{array}$ \\
\hline \multirow[t]{2}{*}{ Currently married } & 0.436 & Sex ratio & $\begin{array}{c}0.018 \\
(0.015)\end{array}$ & $\begin{array}{c}0.029 \\
(0.017)\end{array}$ & $\begin{array}{c}0.001 \\
(0.019)\end{array}$ & $\begin{array}{c}0.039 \\
(0.024)\end{array}$ \\
\hline & & $\begin{array}{l}\text { Ln (\# Foreign } \\
\text { born) }\end{array}$ & $\begin{array}{c}0.003 \\
(0.010)\end{array}$ & $\begin{array}{c}0.002 \\
(0.012)\end{array}$ & $\begin{array}{c}0.001 \\
(0.010)\end{array}$ & $\begin{array}{l}-0.002 \\
(0.012)\end{array}$ \\
\hline \multirow[t]{2}{*}{ Own children in household } & 0.291 & Sex ratio & $\begin{array}{c}0.024 \\
(0.015)\end{array}$ & $\begin{array}{c}0.032 \\
(0.018)\end{array}$ & $\begin{array}{c}0.011 \\
(0.019)\end{array}$ & $\begin{array}{c}0.043 \\
(0.024)\end{array}$ \\
\hline & & $\begin{array}{l}\text { Ln (\# Foreign } \\
\text { born) }\end{array}$ & $\begin{array}{c}0.013 \\
(0.010)\end{array}$ & $\begin{array}{c}0.018 \\
(0.013)\end{array}$ & $\begin{array}{c}0.010 \\
(0.010)\end{array}$ & $\begin{array}{c}0.013 \\
(0.012)\end{array}$ \\
\hline \multirow[t]{2}{*}{ Mother in household } & 0.419 & Sex ratio & $\begin{array}{l}-0.046 \\
(0.021)\end{array}$ & $\begin{array}{l}-0.045 \\
(0.022)\end{array}$ & $\begin{array}{l}-0.047 \\
(0.026)\end{array}$ & $\begin{array}{l}-0.061 \\
(0.030)\end{array}$ \\
\hline & & $\begin{array}{l}\text { Ln (\# Foreign } \\
\text { born) }\end{array}$ & $\begin{array}{l}-0.006 \\
(0.015)\end{array}$ & $\begin{array}{l}-0.014 \\
(0.016)\end{array}$ & $\begin{array}{c}0.001 \\
(0.014)\end{array}$ & $\begin{array}{l}-0.008 \\
(0.018)\end{array}$ \\
\hline \multirow[t]{2}{*}{ Family size } & 4.327 & Sex ratio & $\begin{array}{l}-0.299 \\
(0.165)\end{array}$ & $\begin{array}{l}-0.382 \\
(0.188)\end{array}$ & $\begin{array}{l}-0.414 \\
(0.203)\end{array}$ & $\begin{array}{l}-0.518 \\
(0.254)\end{array}$ \\
\hline & & $\begin{array}{l}\text { Ln (\# Foreign } \\
\text { born) }\end{array}$ & $\begin{array}{c}0.120 \\
(0.123)\end{array}$ & $\begin{array}{c}0.163 \\
(0.144)\end{array}$ & $\begin{array}{c}0.161 \\
(0.116)\end{array}$ & $\begin{array}{c}0.214 \\
(0.144)\end{array}$ \\
\hline \multirow[t]{2}{*}{ \# Aged 14-69 in family } & 3.395 & Sex ratio & $\begin{array}{l}-0.460 \\
(0.120)\end{array}$ & $\begin{array}{l}-0.531 \\
(0.137)\end{array}$ & $\begin{array}{l}-0.629 \\
(0.148)\end{array}$ & $\begin{array}{l}-0.720 \\
(0.186)\end{array}$ \\
\hline & & $\begin{array}{l}\text { Ln (\# Foreign } \\
\text { born) }\end{array}$ & $\begin{array}{l}-0.016 \\
(0.089)\end{array}$ & $\begin{array}{c}0.004 \\
(0.104)\end{array}$ & $\begin{array}{c}0.047 \\
(0.084)\end{array}$ & $\begin{array}{c}0.074 \\
(0.105)\end{array}$ \\
\hline \multirow[t]{2}{*}{$\begin{array}{l}\text { Respondent is head of } \\
\text { household }\end{array}$} & 0.401 & Sex ratio & $\begin{array}{c}0.027 \\
(0.017)\end{array}$ & $\begin{array}{c}0.045 \\
(0.019)\end{array}$ & $\begin{array}{c}0.027 \\
(0.022)\end{array}$ & $\begin{array}{c}0.061 \\
(0.027)\end{array}$ \\
\hline & & $\begin{array}{l}\text { Ln (\# Foreign } \\
\text { born) }\end{array}$ & $\begin{array}{c}0.014 \\
(0.012)\end{array}$ & $\begin{array}{c}0.011 \\
(0.014)\end{array}$ & $\begin{array}{c}0.011 \\
(0.011)\end{array}$ & $\begin{array}{c}0.005 \\
(0.014)\end{array}$ \\
\hline
\end{tabular}


TABLE VI (cont.)

OLS and IV Estimates for Men Aged 20-35

\begin{tabular}{|c|c|c|c|c|c|c|}
\hline \multirow{4}{*}{ Dependent variable } & \multirow{4}{*}{$\begin{array}{c}\text { Mean } \\
\text { (1) }\end{array}$} & \multirow{4}{*}{ Regressor } & \multicolumn{4}{|c|}{ Model } \\
\hline & & & \multicolumn{2}{|c|}{$\begin{array}{c}\text { Foreign born ratio } \\
\text { endogenous }\end{array}$} & \multicolumn{2}{|c|}{$\begin{array}{c}\text { Foreign stock ratio } \\
\text { endogenous }\end{array}$} \\
\hline & & & OLS & $2 \mathrm{SLS}$ & OLS & 2SLS \\
\hline & & & $(2)$ & (3) & (4) & $(5)$ \\
\hline \multirow{3}{*}{ In the labor force } & \multicolumn{4}{|c|}{ B. Economic Outcomes } & & \\
\hline & 0.949 & Sex ratio & $\begin{array}{c}0.005 \\
(0.007)\end{array}$ & $\begin{array}{c}0.009 \\
(0.008)\end{array}$ & $\begin{array}{c}0.002 \\
(0.009)\end{array}$ & $\begin{array}{c}0.012 \\
(0.010)\end{array}$ \\
\hline & & $\begin{array}{l}\text { Ln (\# Foreign } \\
\text { born) }\end{array}$ & $\begin{array}{c}0.002 \\
(0.004)\end{array}$ & $\begin{array}{c}0.003 \\
(0.005)\end{array}$ & $\begin{array}{c}0.002 \\
(0.004)\end{array}$ & $\begin{array}{c}0.002 \\
(0.005)\end{array}$ \\
\hline \multirow[t]{2}{*}{ Occupational income score } & 786.8 & Sex ratio & $\begin{array}{c}9.53 \\
(13.18)\end{array}$ & $\begin{array}{c}11.0 \\
(14.74)\end{array}$ & $\begin{array}{c}4.43 \\
(16.94)\end{array}$ & $\begin{array}{c}14.86 \\
(20.01)\end{array}$ \\
\hline & & $\begin{array}{c}\text { Ln (\# of } \\
\text { Immigrants) }\end{array}$ & $\begin{array}{l}-1.53 \\
(8.80)\end{array}$ & $\begin{array}{c}-2.26 \\
(10.44)\end{array}$ & $\begin{array}{l}-2.86 \\
(8.50)\end{array}$ & $\begin{array}{c}-3.70 \\
(10.52)\end{array}$ \\
\hline \multirow[t]{2}{*}{ Log occupational wage } & 6.581 & Sex ratio & $\begin{array}{c}0.032 \\
(0.019)\end{array}$ & $\begin{array}{c}0.036 \\
(0.021)\end{array}$ & $\begin{array}{c}0.032 \\
(0.024)\end{array}$ & $\begin{array}{c}0.049 \\
(0.029)\end{array}$ \\
\hline & & $\begin{array}{c}\text { Ln (\# of } \\
\text { Immigrants) }\end{array}$ & $\begin{array}{c}0.005 \\
(0.013)\end{array}$ & $\begin{array}{c}0.008 \\
(0.015)\end{array}$ & $\begin{array}{c}0.001 \\
(0.012)\end{array}$ & $\begin{array}{c}0.004 \\
(0.015)\end{array}$ \\
\hline \multirow[t]{2}{*}{ Spouse's income score } & 26.67 & Sex ratio & $\begin{array}{l}-9.49 \\
(4.78)\end{array}$ & $\begin{array}{l}-12.62 \\
(5.34)\end{array}$ & $\begin{array}{r}-14.01 \\
(6.06)\end{array}$ & $\begin{array}{l}-17.10 \\
(7.19)\end{array}$ \\
\hline & & $\begin{array}{c}\text { Ln (\# of } \\
\text { Immigrants) }\end{array}$ & $\begin{array}{c}0.83 \\
(3.28)\end{array}$ & $\begin{array}{l}0.063 \\
(3.85)\end{array}$ & $\begin{array}{c}2.12 \\
(3.12)\end{array}$ & $\begin{array}{c}1.72 \\
(3.83)\end{array}$ \\
\hline \multirow[t]{2}{*}{$\begin{array}{l}\text { Combined husband and } \\
\text { wife income score }\end{array}$} & 813.4 & Sex ratio & $\begin{array}{c}-0.21 \\
(14.22)\end{array}$ & $\begin{array}{c}-1.83 \\
(15.90)\end{array}$ & $\begin{array}{c}-9.95 \\
(18.20)\end{array}$ & $\begin{array}{c}-2.48 \\
(21.55)\end{array}$ \\
\hline & & $\begin{array}{c}\text { Ln (\# of } \\
\text { Immigrants) }\end{array}$ & $\begin{array}{l}-0.59 \\
(9.54)\end{array}$ & $\begin{array}{c}-2.06 \\
(11.30)\end{array}$ & $\begin{array}{l}-0.60 \\
(9.15)\end{array}$ & $\begin{array}{c}-1.82 \\
(11.33)\end{array}$ \\
\hline \multirow[t]{2}{*}{ Family income score } & 1589.1 & Sex ratio & $\begin{array}{l}-181.2 \\
(54.7)\end{array}$ & $\begin{array}{l}-223.7 \\
(62.0)\end{array}$ & $\begin{array}{l}-250.8 \\
(68.5)\end{array}$ & $\begin{array}{l}-303.3 \\
(84.4)\end{array}$ \\
\hline & & $\begin{array}{c}\text { Ln (\# of } \\
\text { Immigrants) }\end{array}$ & $\begin{array}{l}-38.4 \\
(39.7)\end{array}$ & $\begin{array}{l}-18.9 \\
(46.6)\end{array}$ & $\begin{array}{l}-13.7 \\
(37.9)\end{array}$ & $\begin{array}{c}10.4 \\
(46.9)\end{array}$ \\
\hline \multirow[t]{2}{*}{$\begin{array}{c}\text { Family income score per } \\
\text { member aged } 14-69\end{array}$} & 507.3 & Sex ratio & $\begin{array}{c}7.87 \\
(10.23)\end{array}$ & $\begin{array}{c}4.21 \\
(11.53)\end{array}$ & $\begin{array}{c}7.96 \\
(13.04)\end{array}$ & $\begin{array}{c}5.71 \\
(15.63)\end{array}$ \\
\hline & & $\begin{array}{c}\text { Ln (\# of } \\
\text { Immigrants) }\end{array}$ & $\begin{array}{l}-7.09 \\
(7.05)\end{array}$ & $\begin{array}{l}-7.67 \\
(8.36)\end{array}$ & $\begin{array}{l}-8.18 \\
(6.78)\end{array}$ & $\begin{array}{l}-8.22 \\
(8.38)\end{array}$ \\
\hline
\end{tabular}

The table reports OLS and 2SLS estimates of equation (1) in the text. Other regressors in the model include year, ethnicity, and age effects and dummies for nativity status. Standard errors adjusted for ethnicity-year clustering are reported in parentheses. The endogenous variables in columns (3) and (5) are the sex ratio and number of immigrants estimated from the census. The excluded instruments are the sex ratio and number of arrivals reported by US immigration authorities. The sample includes 48,984 observations from the 1910, 1920, and 1940 IPUMS files, except for the log wage results, which use a sample of 46,638 , and some of the income variables, for which sample sizes are slightly below the maximum possible. 
TABLE VII

Interactions with Group Endogamy Rates

\begin{tabular}{|c|c|c|c|c|c|c|}
\hline \multirow[b]{2}{*}{ Dependent variable } & \multicolumn{3}{|c|}{ OLS } & \multicolumn{3}{|c|}{ 2SLS } \\
\hline & $\begin{array}{c}\text { Main effect } \\
\text { (1) }\end{array}$ & $\begin{array}{l}\text { Interaction } \\
\text { effect } \\
\text { (2) }\end{array}$ & $\begin{array}{c}\text { Effect at mean } \\
\text { (3) }\end{array}$ & $\begin{array}{c}\text { Main effect } \\
\text { (4) }\end{array}$ & $\begin{array}{l}\text { Interaction } \\
\text { effect } \\
\text { (5) }\end{array}$ & $\begin{array}{c}\text { Effect at mean } \\
\text { (6) }\end{array}$ \\
\hline & \multicolumn{6}{|c|}{ A. Women } \\
\hline Ever married & $\begin{array}{l}-0.069 \\
(0.061)\end{array}$ & $\begin{array}{c}0.412 \\
(0.121)\end{array}$ & 0.115 & $\begin{array}{l}-0.178 \\
(0.080)\end{array}$ & $\begin{array}{c}0.784 \\
(0.181)\end{array}$ & 0.172 \\
\hline Mother in household & $\begin{array}{c}0.074 \\
(0.091)\end{array}$ & $\begin{array}{l}-0.390 \\
(0.180)\end{array}$ & -0.100 & $\begin{array}{c}0.106 \\
(0.102)\end{array}$ & $\begin{array}{l}-0.496 \\
(0.230)\end{array}$ & -0.116 \\
\hline Family size & $\begin{array}{l}-0.835 \\
(0.689)\end{array}$ & $\begin{array}{c}1.069 \\
(1.362)\end{array}$ & -0.357 & $\begin{array}{l}-0.830 \\
(0.773)\end{array}$ & $\begin{array}{c}0.805 \\
(1.734)\end{array}$ & -0.470 \\
\hline $\begin{array}{l}\text { Respondent is head of } \\
\text { household }\end{array}$ & $\begin{array}{c}0.020 \\
(0.018)\end{array}$ & $\begin{array}{l}-0.023 \\
(0.036)\end{array}$ & 0.010 & $\begin{array}{c}0.013 \\
(0.020)\end{array}$ & $\begin{array}{c}0.002 \\
(0.045)\end{array}$ & 0.014 \\
\hline In the labor force & $\begin{array}{c}0.088 \\
(0.053)\end{array}$ & $\begin{array}{l}-0.352 \\
(0.105)\end{array}$ & -0.069 & $\begin{array}{c}0.118 \\
(0.064)\end{array}$ & $\begin{array}{l}-0.477 \\
(0.145)\end{array}$ & -0.095 \\
\hline Occupational income score & $\begin{array}{c}55.4 \\
(27.6)\end{array}$ & $\begin{array}{l}-220.5 \\
(54.5)\end{array}$ & -43.2 & $\begin{array}{c}76.1 \\
(31.8)\end{array}$ & $\begin{array}{l}-289.8 \\
(72.9)\end{array}$ & -53.5 \\
\hline Log occupational wage & $\begin{array}{c}0.000 \\
(0.052)\end{array}$ & $\begin{array}{l}-0.096 \\
(0.102)\end{array}$ & -0.043 & $\begin{array}{l}-0.014 \\
(0.057)\end{array}$ & $\begin{array}{l}-0.026 \\
(0.131)\end{array}$ & -0.026 \\
\hline $\begin{array}{l}\text { Combined husband and wife } \\
\text { income score }\end{array}$ & $\begin{array}{l}-67.4 \\
(57.4)\end{array}$ & $\begin{array}{c}311.4 \\
(113.6)\end{array}$ & 71.8 & $\begin{array}{l}-151.9 \\
(70.1)\end{array}$ & $\begin{array}{c}596.9 \\
(159.0)\end{array}$ & 114.9 \\
\hline \multirow[t]{2}{*}{$\begin{array}{l}\text { Family income score per } \\
\text { member aged } 14-69\end{array}$} & $\begin{array}{l}-35.9 \\
(26.6)\end{array}$ & $\begin{array}{l}108.0 \\
(52.5)\end{array}$ & 12.3 & $\begin{array}{l}-40.2 \\
(29.4)\end{array}$ & $\begin{array}{l}117.5 \\
(67.0)\end{array}$ & 12.4 \\
\hline & \multicolumn{6}{|c|}{ B. Men } \\
\hline Ever married & $\begin{array}{c}0.049 \\
(0.064)\end{array}$ & $\begin{array}{l}-0.037 \\
(0.155)\end{array}$ & 0.034 & $\begin{array}{l}-0.134 \\
(0.105)\end{array}$ & $\begin{array}{c}0.535 \\
(0.318)\end{array}$ & 0.089 \\
\hline Mother in household & $\begin{array}{l}-0.024 \\
(0.089)\end{array}$ & $\begin{array}{l}-0.101 \\
(0.218)\end{array}$ & -0.066 & $\begin{array}{c}0.073 \\
(0.135)\end{array}$ & $\begin{array}{l}-0.254 \\
(0.407)\end{array}$ & -0.033 \\
\hline Family size & $\begin{array}{l}-0.894 \\
(0.740)\end{array}$ & $\begin{array}{c}1.334 \\
(1.804)\end{array}$ & -0.338 & $\begin{array}{l}-1.069 \\
(0.112)\end{array}$ & $\begin{array}{c}1.730 \\
(3.379)\end{array}$ & -0.348 \\
\hline $\begin{array}{l}\text { Respondent is head of } \\
\text { household }\end{array}$ & $\begin{array}{c}0.081 \\
(0.073)\end{array}$ & $\begin{array}{l}-0.121 \\
(0.178)\end{array}$ & 0.031 & $\begin{array}{l}-0.064 \\
(0.116)\end{array}$ & $\begin{array}{c}0.360 \\
(0.348)\end{array}$ & 0.086 \\
\hline In the labor force & $\begin{array}{l}-0.022 \\
(0.025)\end{array}$ & $\begin{array}{c}0.084 \\
(0.060)\end{array}$ & 0.013 & $\begin{array}{l}-0.091 \\
(0.037)\end{array}$ & $\begin{array}{c}0.311 \\
(0.111)\end{array}$ & 0.039 \\
\hline Occupational income score & $\begin{array}{c}-3.3 \\
(48.4)\end{array}$ & $\begin{array}{c}31.6 \\
(117.8)\end{array}$ & 9.9 & $\begin{array}{l}-31.9 \\
(70.2)\end{array}$ & $\begin{array}{l}136.0 \\
(212.4)\end{array}$ & 24.8 \\
\hline Log occupational wage & $\begin{array}{l}-0.018 \\
(0.068)\end{array}$ & $\begin{array}{c}0.153 \\
(0.165)\end{array}$ & 0.046 & $\begin{array}{l}-0.040 \\
(0.098)\end{array}$ & $\begin{array}{l}0.245 \\
(0.297)\end{array}$ & 0.062 \\
\hline $\begin{array}{l}\text { Combined husband and wife } \\
\text { income score }\end{array}$ & $\begin{array}{c}28.6 \\
(53.9)\end{array}$ & $\begin{array}{l}-71.3 \\
(131.4)\end{array}$ & -1.1 & $\begin{array}{l}28.9 \\
(78.8)\end{array}$ & $\begin{array}{l}-58.7 \\
(238.6)\end{array}$ & 4.4 \\
\hline $\begin{array}{l}\text { Family income score per } \\
\text { member aged } 14-69\end{array}$ & $\begin{array}{c}32.0 \\
(41.9)\end{array}$ & $\begin{array}{l}-57.3 \\
(102.1)\end{array}$ & 8.1 & $\begin{array}{c}76.0 \\
(64.1)\end{array}$ & $\begin{array}{l}-203.1 \\
(193.5)\end{array}$ & -8.7 \\
\hline
\end{tabular}

The table reports estimates of equation (3) in the text. Standard errors adjusted for ethnicity-year clustering are reported in parentheses. The endogamy rate used to construct interaction terms is the sex-specific proportion of married people married endogamously in 1910. The estimation uses data for 1920 and 1940 only. The sample includes 41,980 women aged 18-33 and 38,920 men aged 20-35, except for the samples used to estimate wage and income effects. 
TABLE VIII

Effects on the Third Generation

\begin{tabular}{|c|c|c|c|c|c|c|c|}
\hline \multirow[b]{2}{*}{ Dependent variable } & \multirow[b]{2}{*}{ Regressor } & \multicolumn{3}{|c|}{ Children Under 5} & \multicolumn{3}{|c|}{ All Children } \\
\hline & & $\begin{array}{l}\text { Dependent } \\
\text { mean } \\
\text { (1) }\end{array}$ & $\begin{array}{l}\text { OLS } \\
\text { (2) }\end{array}$ & $\begin{array}{c}\text { 2SLS } \\
\text { (3) }\end{array}$ & $\begin{array}{l}\text { Dependent } \\
\text { mean } \\
(4)\end{array}$ & $\begin{array}{l}\text { OLS } \\
(5)\end{array}$ & $\begin{array}{l}\text { 2SLS } \\
(6)\end{array}$ \\
\hline \multirow[t]{2}{*}{ Mother is married } & Sex ratio & 0.982 & $\begin{array}{c}0.010 \\
(0.007)\end{array}$ & $\begin{array}{c}0.014 \\
(0.008)\end{array}$ & 0.973 & $\begin{array}{l}-0.008 \\
(0.008)\end{array}$ & $\begin{array}{c}0.008 \\
(0.009)\end{array}$ \\
\hline & $\begin{array}{l}\text { Ln (\# Foreign } \\
\text { born) }\end{array}$ & & $\begin{array}{c}0.008 \\
(0.004)\end{array}$ & $\begin{array}{c}0.012 \\
(0.005)\end{array}$ & & $\begin{array}{l}-0.002 \\
(0.005)\end{array}$ & $\begin{array}{c}0.000 \\
(0.006)\end{array}$ \\
\hline \multirow[t]{2}{*}{ Family size } & Sex ratio & 4.89 & $\begin{array}{c}0.039 \\
(0.121)\end{array}$ & $\begin{array}{c}0.024 \\
(0.139)\end{array}$ & 5.17 & $\begin{array}{l}-0.062 \\
(0.195)\end{array}$ & $\begin{array}{l}-0.040 \\
(0.226)\end{array}$ \\
\hline & $\begin{array}{l}\text { Ln (\# Foreign } \\
\text { born) }\end{array}$ & & $\begin{array}{c}0.285 \\
(0.087)\end{array}$ & $\begin{array}{c}0.301 \\
(0.105)\end{array}$ & & $\begin{array}{c}0.274 \\
(0.147)\end{array}$ & $\begin{array}{c}0.287 \\
(0.175)\end{array}$ \\
\hline \multirow[t]{2}{*}{ \# Aged 14-69 in family } & Sex ratio & 2.415 & $\begin{array}{l}-0.171 \\
(0.054)\end{array}$ & $\begin{array}{l}-0.195 \\
(0.061)\end{array}$ & 2.418 & $\begin{array}{l}-0.150 \\
(0.046)\end{array}$ & $\begin{array}{l}-0.178 \\
(0.053)\end{array}$ \\
\hline & $\begin{array}{l}\text { Ln (\# Foreign } \\
\text { born) }\end{array}$ & & $\begin{array}{l}-0.023 \\
(0.034)\end{array}$ & $\begin{array}{l}-0.029 \\
(0.041)\end{array}$ & & $\begin{array}{l}-0.051 \\
(0.029)\end{array}$ & $\begin{array}{l}-0.075 \\
(0.035)\end{array}$ \\
\hline \multirow[t]{2}{*}{ Mother works } & Sex ratio & 0.055 & $\begin{array}{l}-0.001 \\
(0.012)\end{array}$ & $\begin{array}{l}-0.001 \\
(0.014)\end{array}$ & 0.072 & $\begin{array}{l}-0.019 \\
(0.013)\end{array}$ & $\begin{array}{l}-0.025 \\
(0.014)\end{array}$ \\
\hline & $\begin{array}{l}\text { Ln (\# Foreign } \\
\text { born) }\end{array}$ & & $\begin{array}{l}-0.009 \\
(0.008)\end{array}$ & $\begin{array}{l}-0.008 \\
(0.009)\end{array}$ & & $\begin{array}{l}-0.004 \\
(0.008)\end{array}$ & $\begin{array}{c}0.006 \\
(0.010)\end{array}$ \\
\hline \multirow[t]{2}{*}{$\begin{array}{l}\text { Mother's occupational } \\
\text { income score }\end{array}$} & Sex ratio & 24.46 & $\begin{array}{l}-9.54 \\
(6.44)\end{array}$ & $\begin{array}{l}-10.14 \\
(7.26)\end{array}$ & 35.85 & $\begin{array}{l}-15.76 \\
(7.32)\end{array}$ & $\begin{array}{l}-19.08 \\
(8.30)\end{array}$ \\
\hline & $\begin{array}{l}\text { Ln (\# Foreign } \\
\text { born) }\end{array}$ & & $\begin{array}{l}-6.53 \\
(4.06)\end{array}$ & $\begin{array}{l}-7.30 \\
(4.90)\end{array}$ & & $\begin{array}{l}-5.85 \\
(4.65)\end{array}$ & $\begin{array}{l}-2.40 \\
(5.56)\end{array}$ \\
\hline \multirow[t]{2}{*}{$\begin{array}{l}\text { Father's occupational } \\
\text { income score }\end{array}$} & Sex ratio & 927.3 & $\begin{array}{c}49.9 \\
(23.6)\end{array}$ & $\begin{array}{l}49.6 \\
(26.6)\end{array}$ & 941.5 & $\begin{array}{c}46.0 \\
(22.0)\end{array}$ & $\begin{array}{l}55.3 \\
(24.9)\end{array}$ \\
\hline & $\begin{array}{l}\text { Ln (\# Foreign } \\
\text { born) }\end{array}$ & & $\begin{array}{c}16.0 \\
(14.8)\end{array}$ & $\begin{array}{c}21.9 \\
(17.8)\end{array}$ & & $\begin{array}{c}18.2 \\
(13.7)\end{array}$ & $\begin{array}{l}15.7 \\
(16.4)\end{array}$ \\
\hline \multirow[t]{2}{*}{ Parents' income score } & Sex ratio & 951.7 & $\begin{array}{c}40.2 \\
(24.0)\end{array}$ & $\begin{array}{c}39.3 \\
(27.0)\end{array}$ & 977.3 & $\begin{array}{c}30.3 \\
(22.7)\end{array}$ & $\begin{array}{c}36.0 \\
(25.7)\end{array}$ \\
\hline & $\begin{array}{l}\text { Ln (\# Foreign } \\
\text { born) }\end{array}$ & & $\begin{array}{c}9.3 \\
(15.1)\end{array}$ & $\begin{array}{c}14.3 \\
(18.2)\end{array}$ & & $\begin{array}{c}12.3 \\
(14.4)\end{array}$ & $\begin{array}{c}13.3 \\
(17.2)\end{array}$ \\
\hline \multirow[t]{2}{*}{$\begin{array}{l}\text { Family income score per } \\
\text { member aged } 14-69\end{array}$} & Sex ratio & 472.5 & $\begin{array}{c}26.0 \\
(11.7)\end{array}$ & $\begin{array}{c}24.1 \\
(13.1)\end{array}$ & 479.6 & $\begin{array}{c}32.6 \\
(11.3)\end{array}$ & $\begin{array}{c}29.0 \\
(12.8)\end{array}$ \\
\hline & $\begin{array}{l}\text { Ln (\# Foreign } \\
\text { born) }\end{array}$ & & $\begin{array}{l}2.5 \\
(7.3)\end{array}$ & $\begin{array}{c}4.5 \\
(8.8)\end{array}$ & & $\begin{array}{l}10.9 \\
(7.3)\end{array}$ & $\begin{array}{l}13.7 \\
(8.7)\end{array}$ \\
\hline $\mathrm{N}$ & & 14,976 & & & 19,190 & & \\
\hline
\end{tabular}

The table reports estimates of equation (1) in the text, weighted by the number of children under age 5 (columns 1-3) or weighted by the total number of children in the household (columns 4-6). Standard errors adjusted for ethnicity-year clustering are reported in parentheses. The sample includes 14,975 children under age 5 and 19,190 children total. Income samples are slightly smaller. 
ever married

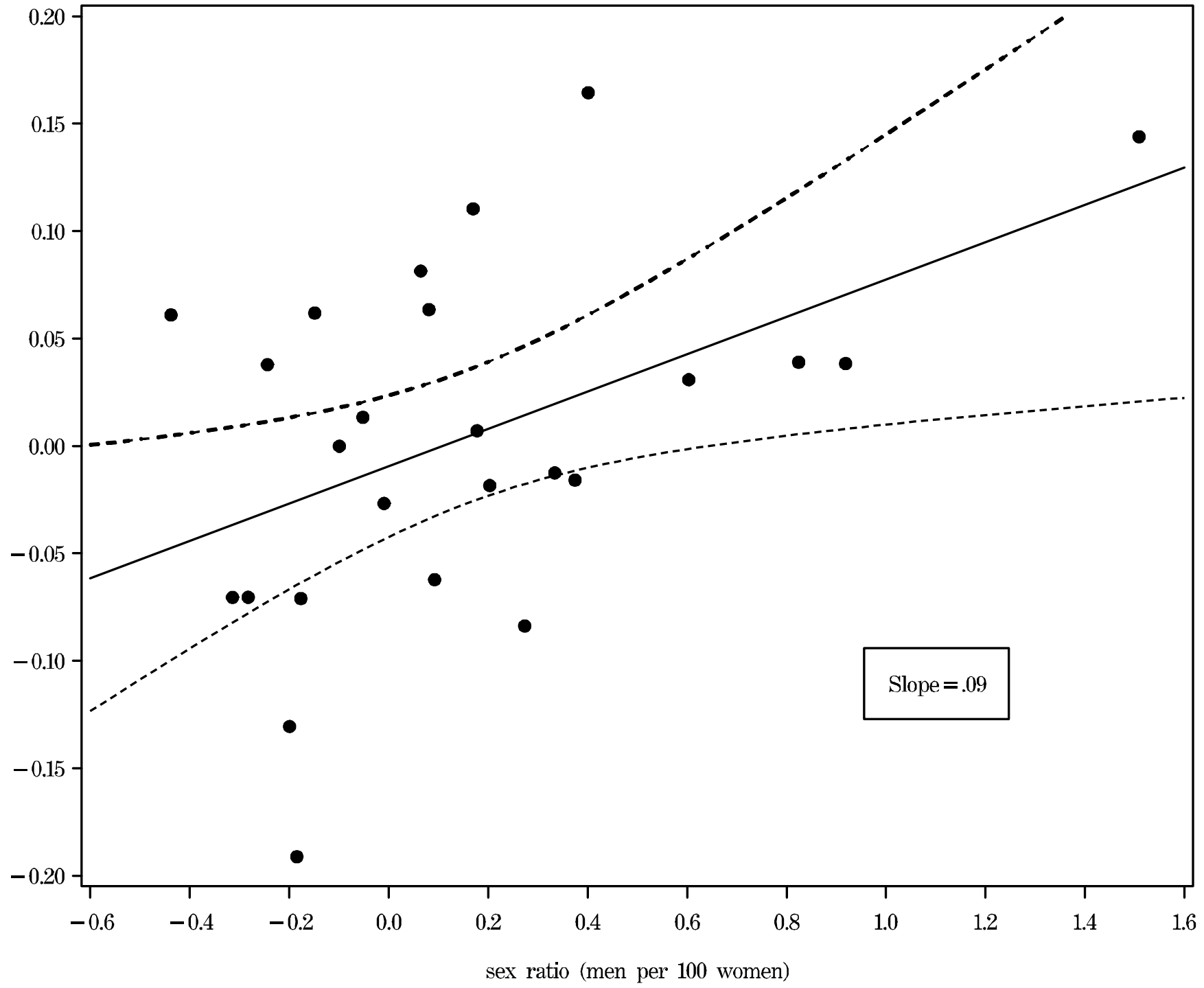

Figure 1a. Ever-married vs. sex ratio in ethnic group.

Native born women aged 18-33 in the 1910, 1920, and 1940 IPUMS.

Controls for year and number of immigrants. 
ever married

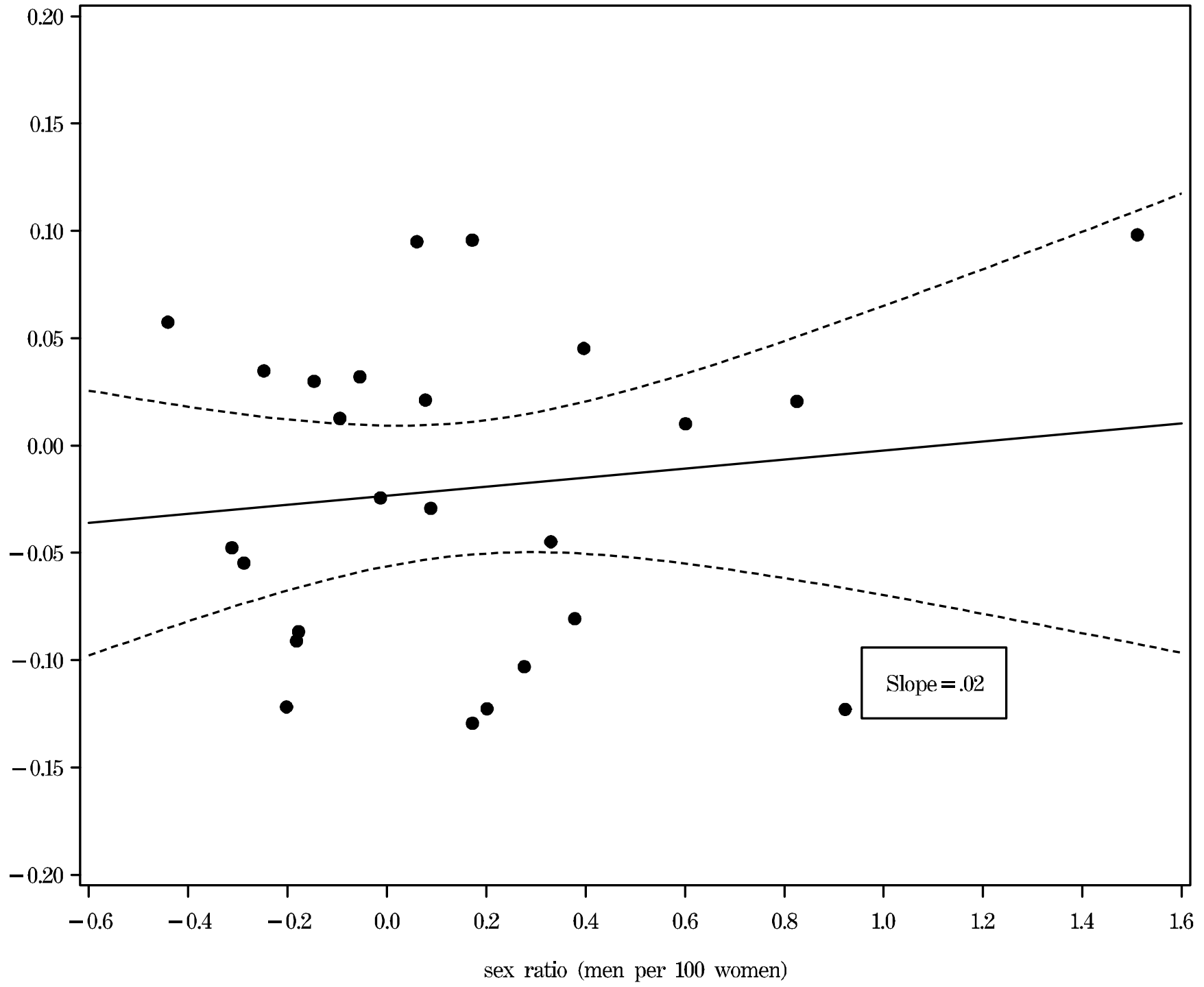

Figure 1b. Ever-married vs. sex ratio in ethnic group.

Native born men aged 20-35 in the 1910, 1920, and 1940 IPUMS.

Controls for year and number of immigrants. 
ever married

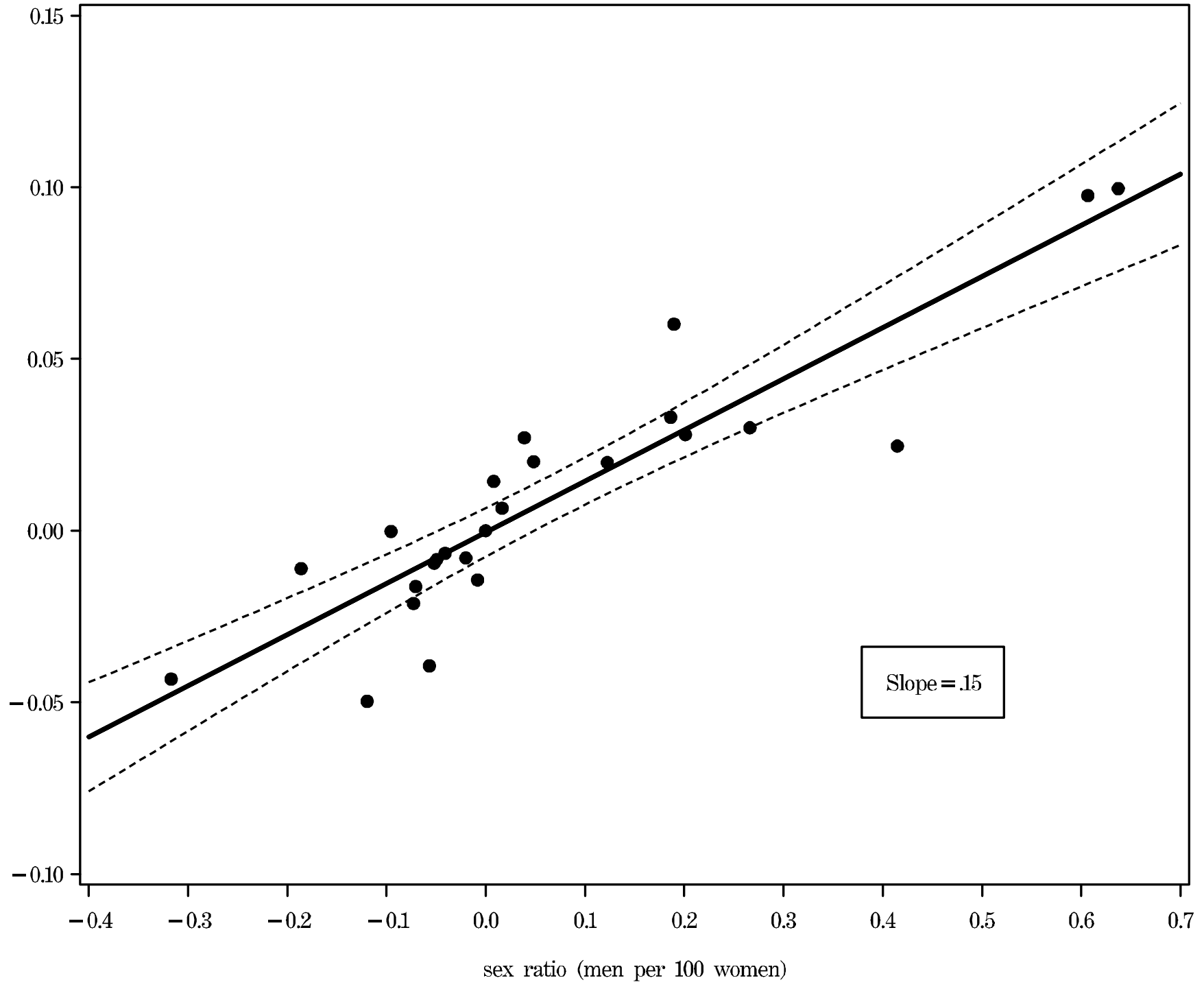

Figure 2a. Ever-married vs. sex ratio in ethnic group.

Native born women aged 18-33 in the 1910, 1920, and 1940 IPUMS.

Controls for year, ethnicity, and number of immigrants. 
ever married

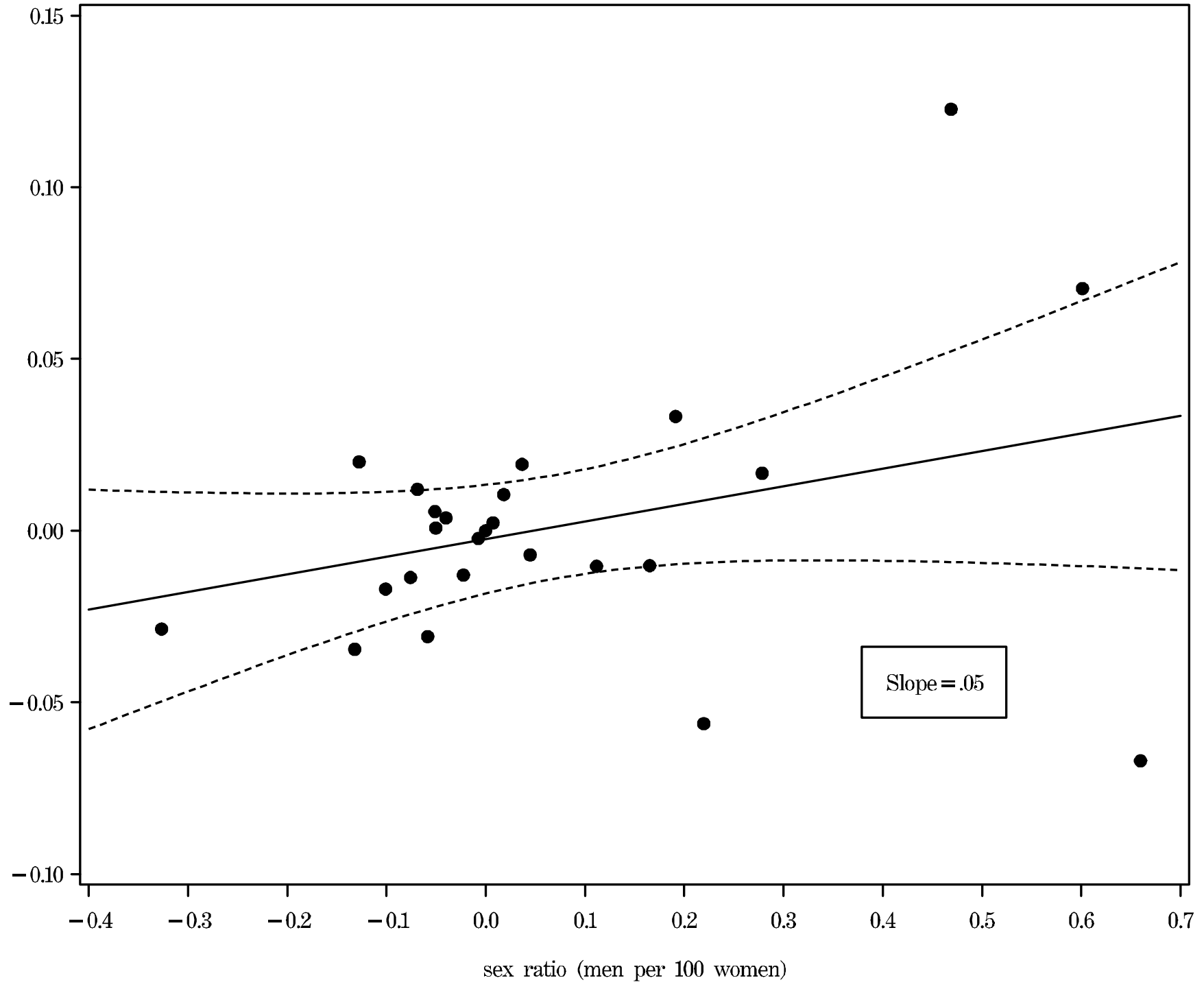

Figure 2b. Ever-married vs. sex ratio in ethnic group.

Native born men aged 20-35 in the 1910, 1920, and 1940 IPUMS.

Controls for year, ethnicity, and number of immigrants. 
ever married

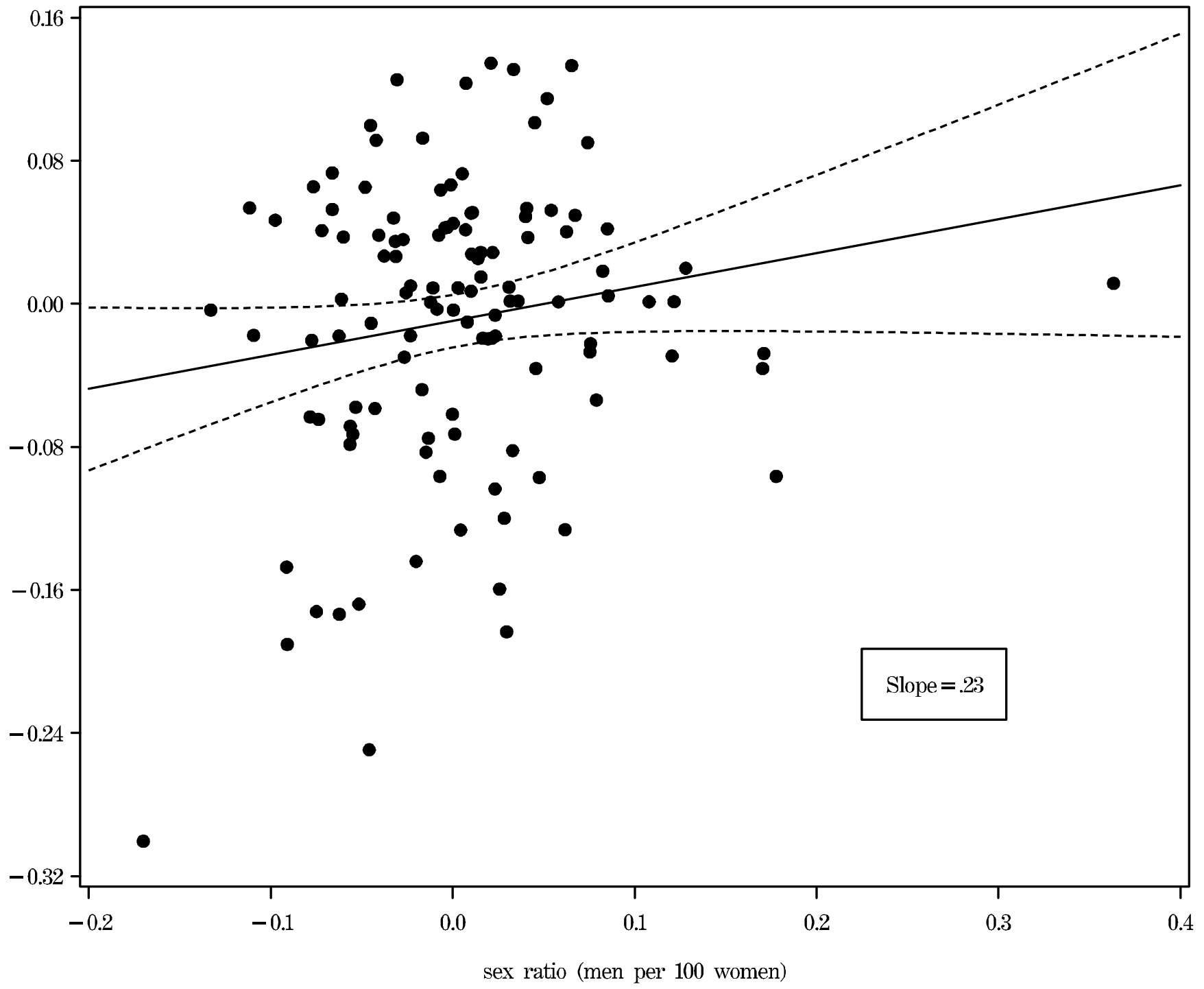

Figure 3a. Ever-married vs. sex ratio in state of residence.

Native born women aged 18-33 in the 1910, 1920, and 1940 IPUMS.

Controls for year and native population size. 
ever married

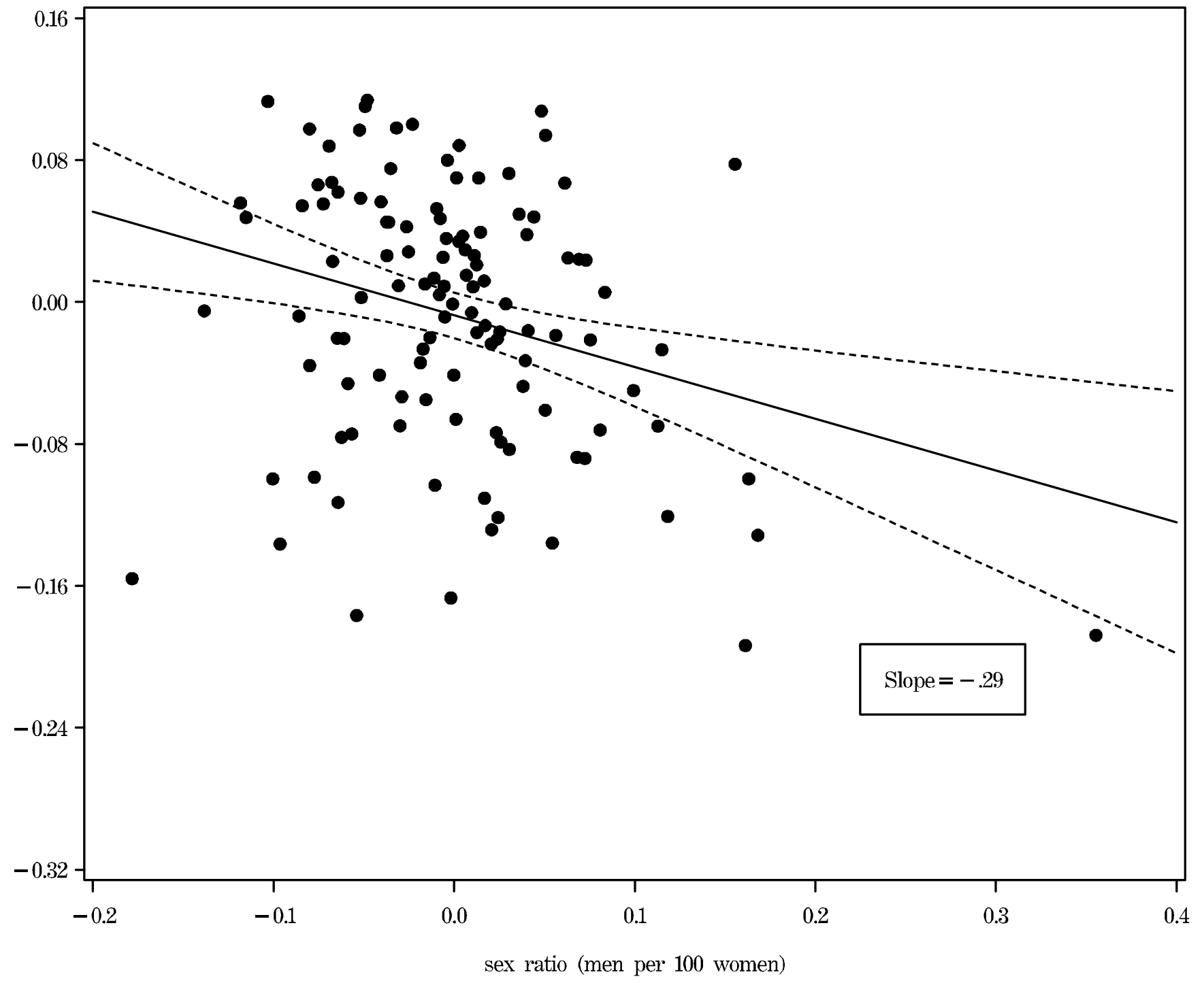

Figure 3b. Ever-married vs. sex ratio in state of residence.

Native born men aged 20-35 in the 1910, 1920, and 1940 IPUMS.

Controls for year and native population size. 
ever married

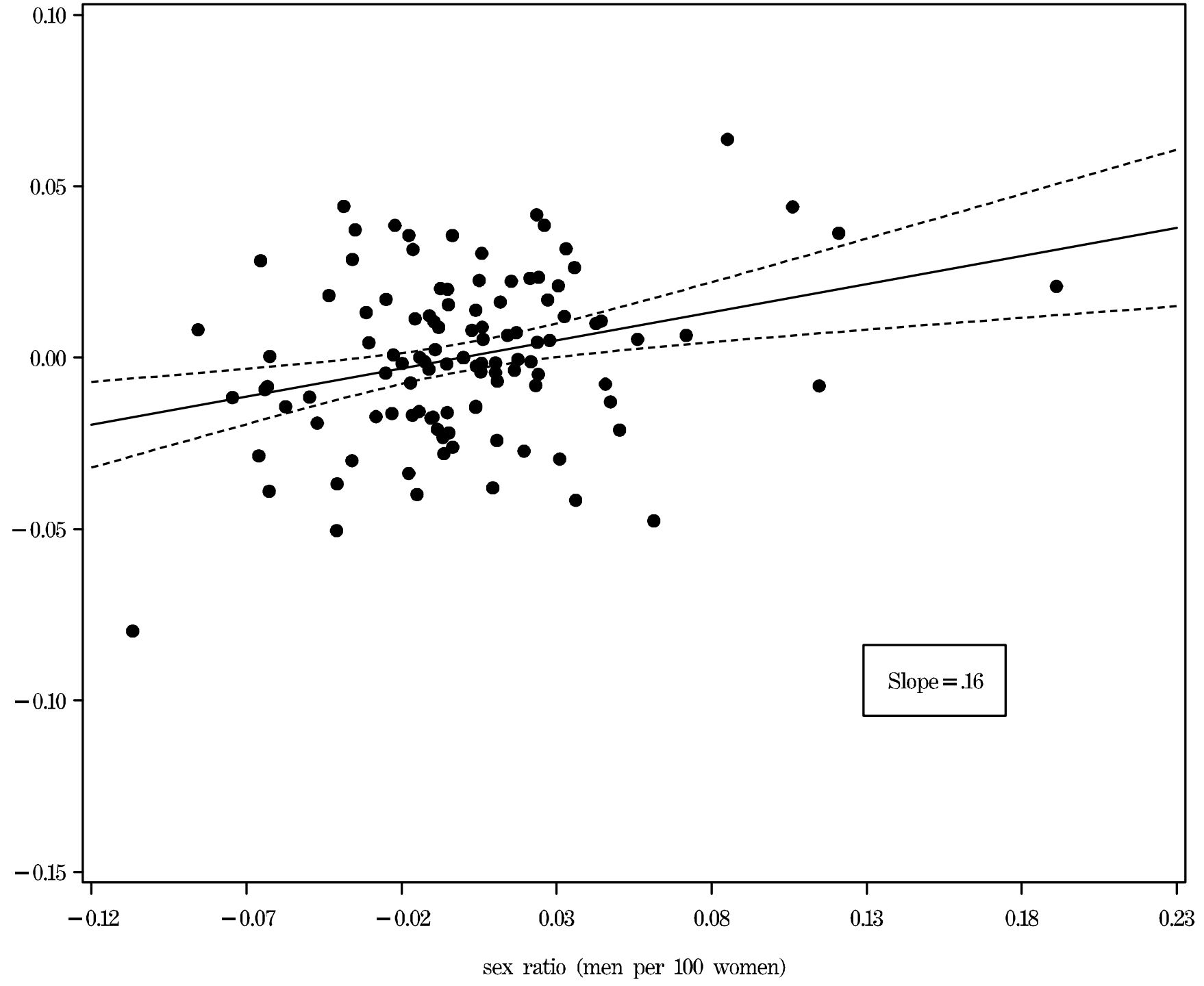

Figure 4a. Ever-married vs. sex ratio in state of residence.

Native born women aged 18-33 in the 1910, 1920, and 1940 IPUMS.

Controls for year, state, and native population size. 
ever married

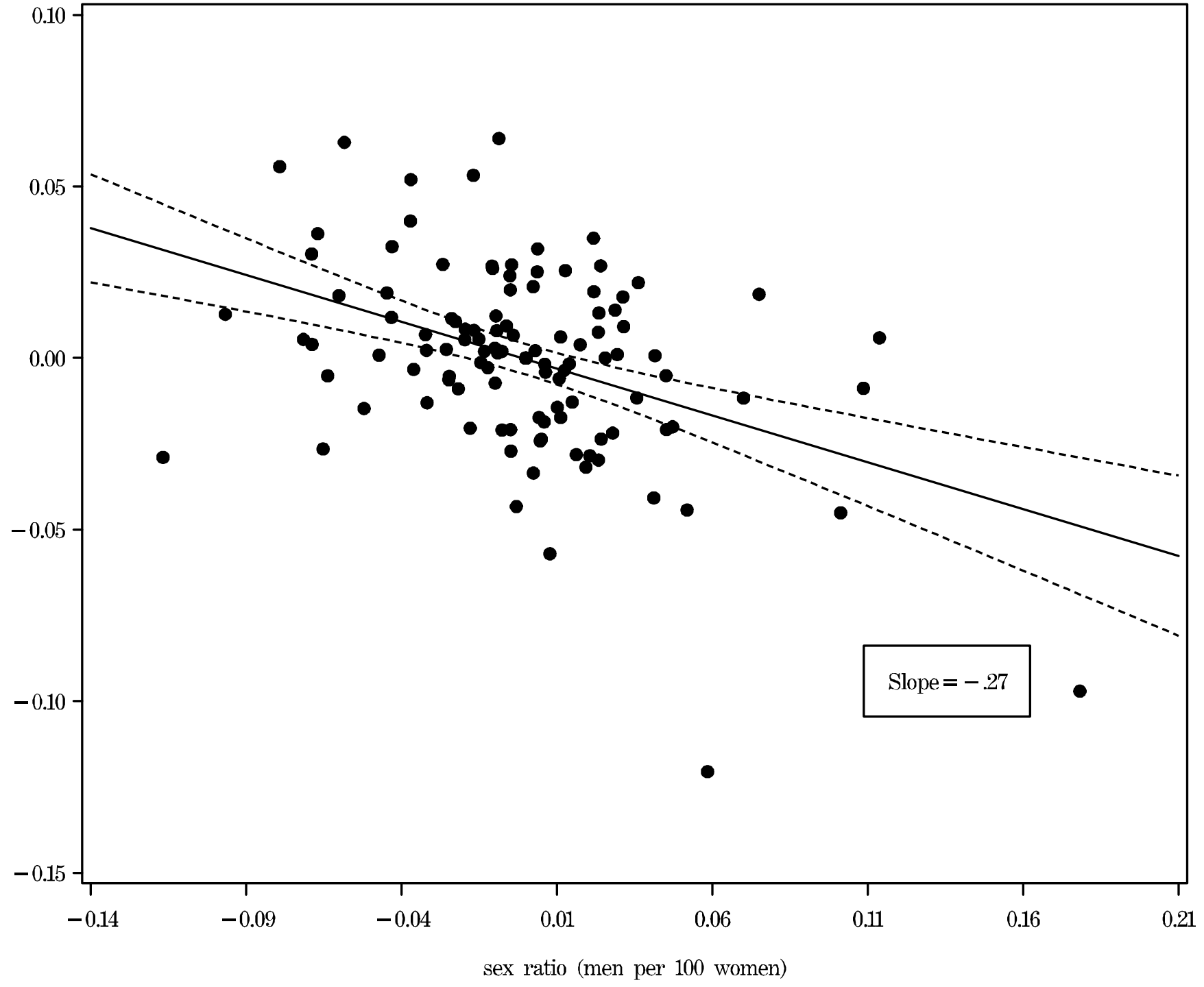

Figure $4 \mathrm{~b}$. Ever-married vs. sex ratio in state of residence.

Native born men aged 20-35 in the 1910, 1920, and 1940 IPUMS.

Controls for year, state, and native populaiton size. 


\section{IZA Discussion Papers}

\author{
No. Author(s) \\ 355 \\ J. Kluve \\ H. Lehmann \\ C. M. Schmidt \\ 356
C. Heady
T. Mitrakos
P. Tsakloglou
C. Knoppik
T. Beissinger \\ 357
}

$358 \quad$ T. Beissinger
O. Buesse

M. Pflüger

J. Hansen

M. Lofstrom

M. C. Berger

J. S. Earle

K. Z. Sabirianova

362
J. Angrist
V. Lavy

363

H. Antecol

D. A. Cobb-Clark

S. J. Trejo

364

M. Jäntti

S. P. Jenkins

365

H. S. Nielsen

M. Rosholm

N. Smith

L. Husted

M. C. Regets

C. Dustmann
Title

Area

Date

Disentangling Treatment Effects of Polish Active

$4 / 6$

09/01

Labor Market Policies: Evidence from Matched

Samples

The Distributional Impact of Social Transfers in the European Union: Evidence from the ECHP

How Rigid are Nominal Wages?

1

09/01

Evidence and Implications for Germany

Bismarck versus Beveridge: Which Unemploy-

3

09/01

ment Compensation System is More Prone to

Labor Market Shocks?

A Simple, Analytically Solvable Chamberlinian

2

09/01

Agglomeration Model

The Dynamics of Immigrant Welfare and Labor

Market Behavior

$1 / 3$

$09 / 01$

Worker Training in a Restructuring Economy:

4

$09 / 01$

Evidence from the Russian Transition

New Evidence on Classroom Computers and

6

$09 / 01$

Pupil Learning

Immigration Policy and the Skills of Immigrants

2

09/01

to Australia, Canada, and the United States

Examining the Impact of Macro-Economic 3

Conditions on Income Inequality

$09 / 01$

$09 / 01$

Qualifications, Discrimination, or Assimilation? 1

An Extended Framework for Analysing

Immigrant Wage Gaps

Research and Policy Issues in High-Skilled International Migration: A Perspective with Data from the United States

Parental Background, Primary to Secondary

5

School Transitions, and Wages

How Do Sex Ratios Affect Marriage and Labor

5

$09 / 01$ 